\title{
Ecosystem services in orchards. A review
}

\author{
Constance Demestihas ${ }^{1,2}$ (D) Daniel Plénet ${ }^{1} \cdot$ Michel Génard $^{1} \cdot$ Christiane Raynal $^{3} \cdot$ \\ Françoise Lescourret ${ }^{1}$
}

Accepted: 21 March 2017 / Published online: 4 April 2017

(C) INRA and Springer-Verlag France 2017

\begin{abstract}
Arboriculture must maintain acceptable fruit production levels while preserving natural resources. This duality can be analyzed with the concept of ecosystem service. We reviewed the literature on orchards to explain how ecological functions modified by agricultural practices provide six ecosystem services - fruit production, climate regulation, soil nitrogen availability, water regulation, pest and disease control, and pollination - and which indicators could describe them. The major points are, first, that orchards have a high potential of multiple services. They can sequester from 2.4 to $12.5 \mathrm{t} \mathrm{C} /$ ha/year. Their perennial character and multi-strata habitat, as well as the opportunity of creating diversified hedgerows and cover crops in alleys, may contribute to a high level of biodiversity and related services. Second, every service depends on many functions. Fruit yield, which could reach up to 140 tha in apple orchards, is increased by light interception, carbon allocation, and nitrogen and water uptake. Third, agricultural practices in orchards have a strong impact on ecosystem functions and, consequently, on ecosystem services. Overfertilization enhances nitrogen leaching, which reduces soil nitrogen availability for the plant and deteriorates the quality of drained water. Groundcover increases humification and reduces denitrification and runoff, thus enhancing soil nitrogen availability and water regulation. It also enhances biotic interactions responsible for pest control and pollination. Pruning may increase fruit quality trough a
\end{abstract}

Françoise Lescourret

francoise.lescourret@inra.fr

PSH, INRA, 84000 Avignon, France

2 CTIFL, Centre de Saint-Rémy, Route de Mollégès, 13210 Saint-Rémy de Provence, France

3 CTIFL, Centre de Lanxade, 41 Route des Nébouts, 24130 Prigonrieux, France better carbon allocation but decreases pest control by fostering the dynamics of aphids.

To study multiple ecosystem services in orchards, we suggest using models capable of simulating service profiles and their variation according to management scenarios. We then refer to the available literature to show that conflicts between provisioning and regulating services can be mitigated by agricultural practices. Improved knowledge of soil processes and carbon balance as well as new models that address multiple services are necessary to foster research on ecosystem service relationships in orchards.

Keywords Agricultural management · Fruit production . Climate regulation $\cdot$ Soil nitrogen availability $\cdot$ Water regulation $\cdot$ Pest and disease control $\cdot$ Pollination $\cdot$ Indicator

\section{Content}

1. Introduction

2. Ecosystem services in commercial orchards

2.1. Provisioning service: fruit production in terms of quantity and quality

2.1.1. Organogenesis

2.1.2. Light interception, carbon assimilation and allocation

2.1.3. Water and nitrogen effects

2.2. Regulation and maintenance services

2.2.1. Climate regulation: mitigation of greenhouse gas emissions

2.2.2. Soil nitrogen availability

2.2.3. Water regulation: hydrological cycle and water flow maintenance

2.2.4. Pest and disease control

2.2.5. Life cycle maintenance: pollination

3. Assessing and analyzing multiple ecosystem services in orchards 
3.1. Using models to quantify indicators of ecosystem services and their connections

3.2. Analyzing multiple ecosystem service relationships

4. Conclusions

Acknowledgements

References

\section{Introduction}

Arboriculture today is beset by contradictory demands. On the one hand, there is a pressing demand regarding the quality of products. The quality standards of fruits, most of which are sold to the fresh market, are very high (Codron et al. 2005). At the same time, on a global scale, the fruit sector is very competitive and yield is a great concern for fruit growers. This has led to the intensification of production techniques, especially of pesticide use in orchards worldwide. For example, in 2012, French apple orchards (Fig. 1a and b) received an average of 35 pesticide treatments (MAAF 2014). On the other hand, society has expressed concern about this over-use of agricultural inputs because of their dramatic impact on natural resources and ecosystem functioning, including the pollution of groundwater, subsoil and the atmosphere, as well as the decrease in biodiversity (Geiger et al. 2011; Mottes et al. 2014).

Ecological intensification is aimed at reconciling high yield goals with minimal negative impacts on the environment. This can be done by integrating the management of ecosystem services into crop production systems (Bommarco et al. 2013). During the 1970s, the term "Ecosystem Service" began to appear in the scientific literature, but two important publications in the 1990s, those of Costanza et al. (1997) and of Daily (1997), were actually responsible for initiating ecosystem service research. In these publications, ecosystem services were defined as the wide array of conditions and processes through which ecosystems and their biodiversity confer benefits to humanity. More precisely, the cascade model (Fig. 2) of Haines-Young and Potschin (2009) places ecosystem services in the middle of a 'production chain', which links the entities that define services upstream: biophysical structures and functions and, downstream, the benefits reaped from the services, which are their real value.

The Millennium Ecosystem Assessment (Reid et al. 2005) classified ecosystem services into four categories: regulating, supporting, provisioning and cultural services. However, supporting services are means to human ends, and not ends themselves (Wallace 2007). Based on these considerations, alternative ecosystem service classifications have been proposed. Most recently, the Common International Classification of Ecosystem Services (CICES) was confined to the ecosystem outputs directly consumed or used by a beneficiary, i.e., 'final' services, and thus excluded the supporting services linked to ecosystem functions that underpin these final services (Haines-Young and Potschin 2013).

In sharp contrast to the case of forest ecosystems, which are known for their ability to sequestrate carbon or regulate the water cycle (Krieger 2001; García-Nieto et al. 2013), the concept of ecosystem service has not yet been widely used in fruit orchard research. A major difference between orchard and forest ecosystems is that in orchards, the focus is on the production of consumable and high-quality food, whereas the multi-functionality of wood-producing forests, which is close to the ecosystem service concept, has long been recognized. However, orchards present particular features that could make them interesting for ecosystem service studies. For example, the perennial character of trees, the multi-strata habitat and the plant diversity within the boundaries of orchards (Fig. 1b) may contribute to a high level of biodiversity (Simon et al. 2010). The potential of carbon sequestration by orchard soils could be valorized and increased to contribute to greenhouse gas mitigation (Rodríguez-Entrena et al. 2012).

Managing multiple ecosystem services appears to be a great challenge for agroecosystems (Zhang et al. 2007). In orchards, as in other agroecosystems, this requires broad knowledge about the underlying ecological functions and of the effect, in turn, of agricultural management on these functions. It should be noted that agricultural practices may impact ecosystem services positively, but they might also impact them negatively. This negative impact is called a disservice by some authors (Power 2010, Zhang et al. 2007). Typically, in an orchard, pesticide use has negative consequences on the quality of water (Loewy et al. 2003) or on biodiversity (Floch et al. 2009). Pesticides may disturb food webs since they are not only lethal to crop pests but also to beneficiary insects as well as pollinators (Biddinger et al. 2013; Geiger et al. 2011; Thompson 2003). Herbicides may also disturb natural nutrient decomposition by killing beneficiary earthworms, fungi and bacteria in soil (Oliveira and Merwin 2001; Andersen et al. 2013).

The objective of this review is to describe ecosystem services and their management in orchards, based on an analysis of agroecosystem functioning. This review is based on the CICES classification. The scale of the study is the plot, which is composed of trees, alleys, soil, hedges and various biotic and abiotic elements such as pests, natural enemies, gas, mineral elements and water. In the following section, we review the literature on orchards to explain how ecological functions modified by agricultural practices provide ecosystem services, and we discuss which indicators could best describe ecosystem services. We also consider the negative environmental impacts of agricultural practices. The ecosystem services analyzed include fruit production, climate regulation by mitigation of greenhouse gas emissions, soil nitrogen availability, water regulation in terms of hydrological cycle and water flow maintenance, pest and disease control, and life cycle 
Fig. 1 a: Apple orchard with anti-hail nets over the Golden Delicious variety, in southeastern France (photo credits: C. Demestihas). b: Opilion spider (Hadrobunus grandis) on Crimson Crisp ${ }^{\circledR}$ apple cultivar (photo credits: C. Demestihas)
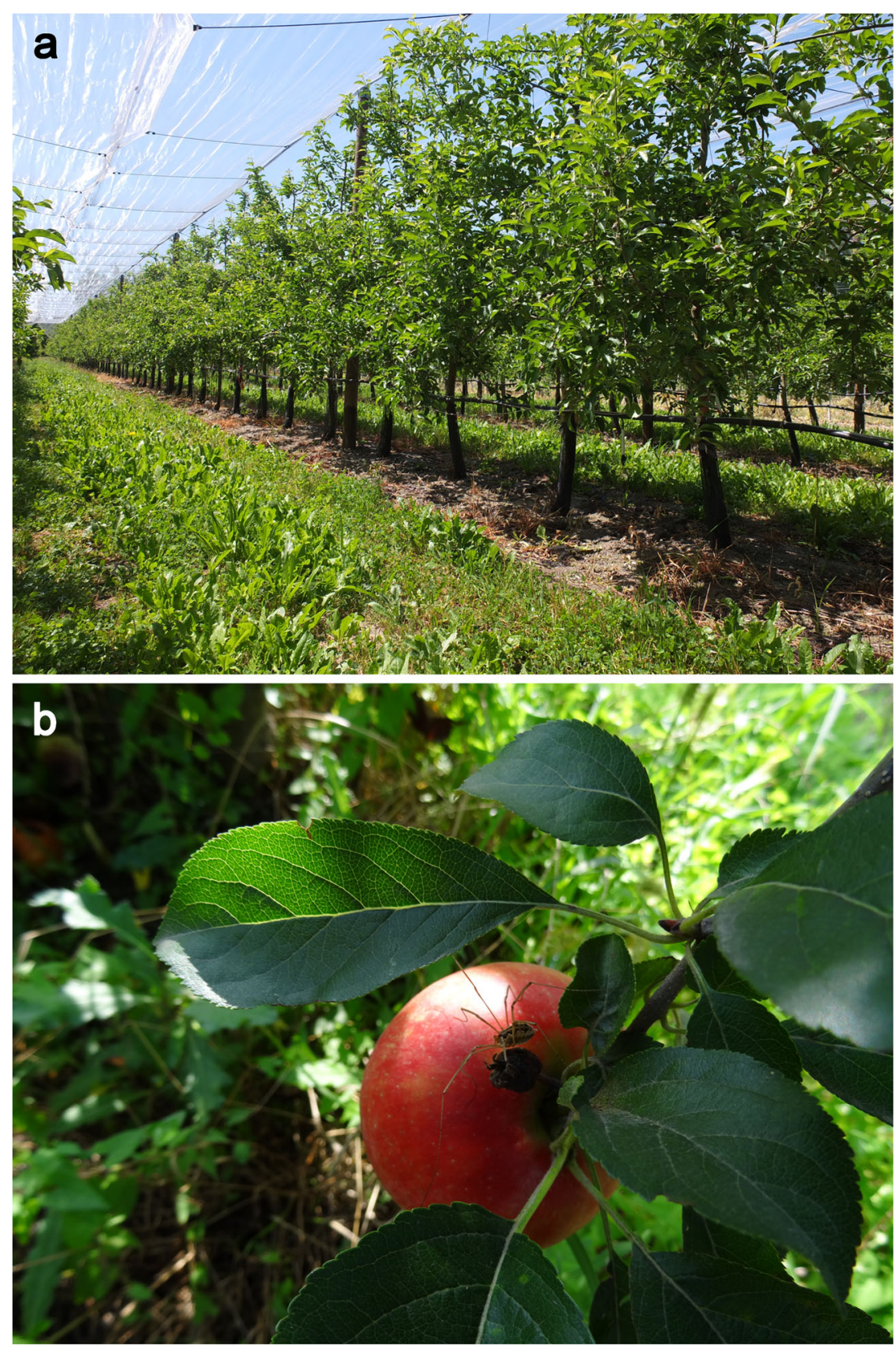

maintenance through pollination. Lastly, we present a general procedure to analyze multiple ecosystem services and their relationships in orchards, using examples from other crops.

\section{Ecosystem services in commercial orchards}

The scheme in Fig. 3 serves as a guide for the following description. In this description we focus, for each of the six selected services and according to the cascade model of Fig. 2, on the underlying ecosystem functions, the way agricultural management influences them and which service indicators could be used. The choice of ecosystem service indicators is a sensitive issue. Authors agree that they should adequately characterize the complexity of the ecosystem but be simple enough to be efficiently monitored and modeled while staying closely linked to ecosystem services and being predictive of changes within ecosystem service relationships (Dale and Polasky 2007; de Groot et al. 2010; van Oudenhoven et al. 2012).

In Fig. 3, many ecosystem functions, which are impacted by climate and soil composition and structure, transform abiotic elements such as nitrogen, carbon or water and/or enable them to flow through the whole orchard system through other compartments such as the atmosphere and the groundwater table and, more globally, towards other surrounding 


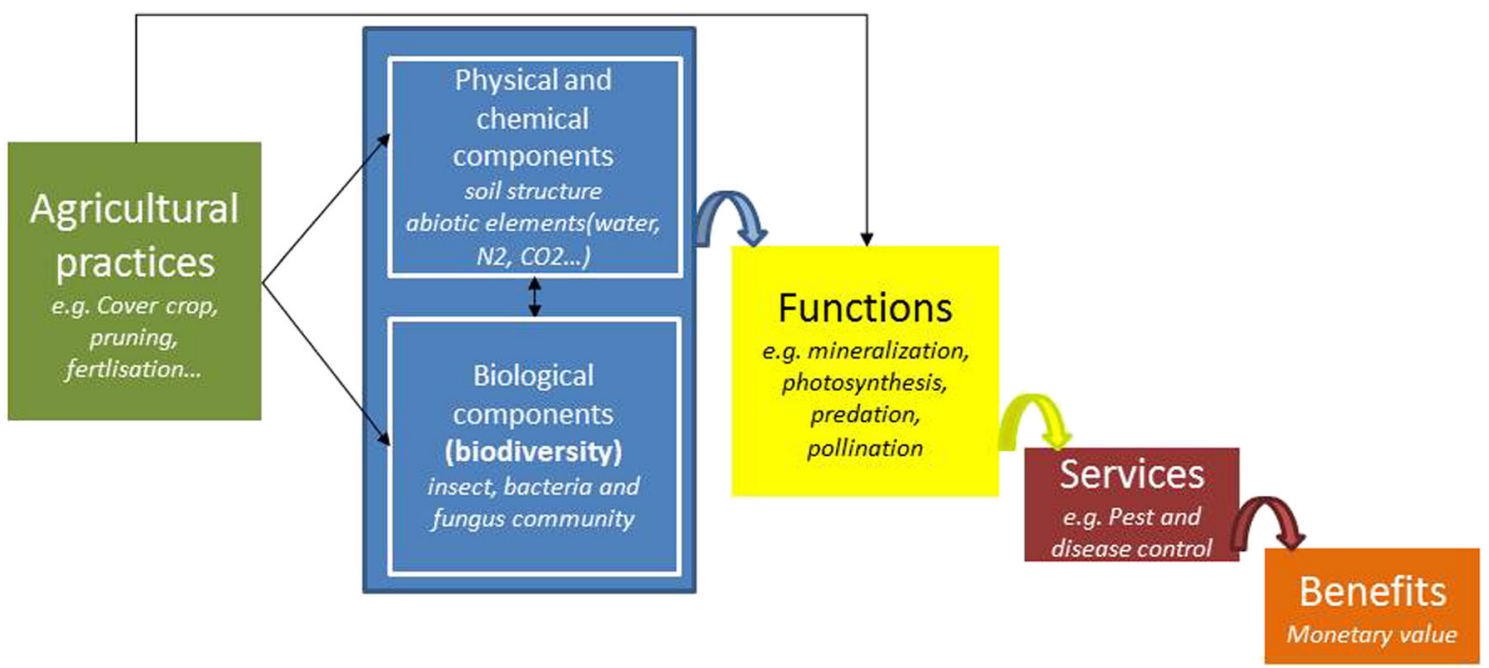

Fig. 2 Relationship between agricultural practices, physical and biological structures, functions, services and benefits according to the "cascade model" of Haines-Young and Potschin (2009) in an agroecosystem

ecosystems. Several connected functions may contribute to one service - evapotranspiration, carbon assimilation and nitrogen uptake are all functions that contribute to fruit production. However, one function may also have an impact on many services. Thus, nitrogen leaching, enhanced by heavy rains and over-fertilization, reduces soil nitrogen availability for the plant and deteriorates the quality of drained water.

In Fig. 3, only the major levers of agricultural management that act upon ecosystem functions are presented. On the one hand, a single function can be affected by several agricultural practices. Thus, nitrogen uptake by trees is influenced by fertilization, cultivar/rootstock choice and groundcover management. On the other hand, a single agricultural practice can affect one or more ecosystem functions, thus modifying several ecosystem services at the same time. Irrigation affects functions that contribute to nitrogen availability, water regulation and fruit production. An agricultural practice can also affect a given function in various ways. Fertilization has contrasting effects on nitrogen leaching and uptake by trees depending on whether it is mineral or organic. In addition, as mentioned above, we consider disturbances to the ecosystem caused by agricultural practices as a result of pollution.
Fig. 3 Linking agricultural management (pink boxes), ecosystem functions (dark green boxes for plant-related functions, orange boxes for soil-related functions and gray boxes for pestrelated functions) and ecosystem services (light green boxes) in the orchard agroecosystem. The pink box, 'Groundcover management', concerns a wide range of options including legumes, cover crops, grasses, pruning wood and senescent leaves left on the ground, etc. Agricultural management, ecosystem functions and ecosystem services are linked by lines and each color is associated with a function. Soil composition and structure as well as climate (violet boxes) are considered separately from agricultural practices. Soil is impacted by groundcover management as well as weed and pest control. Climate is considered to impact all functions

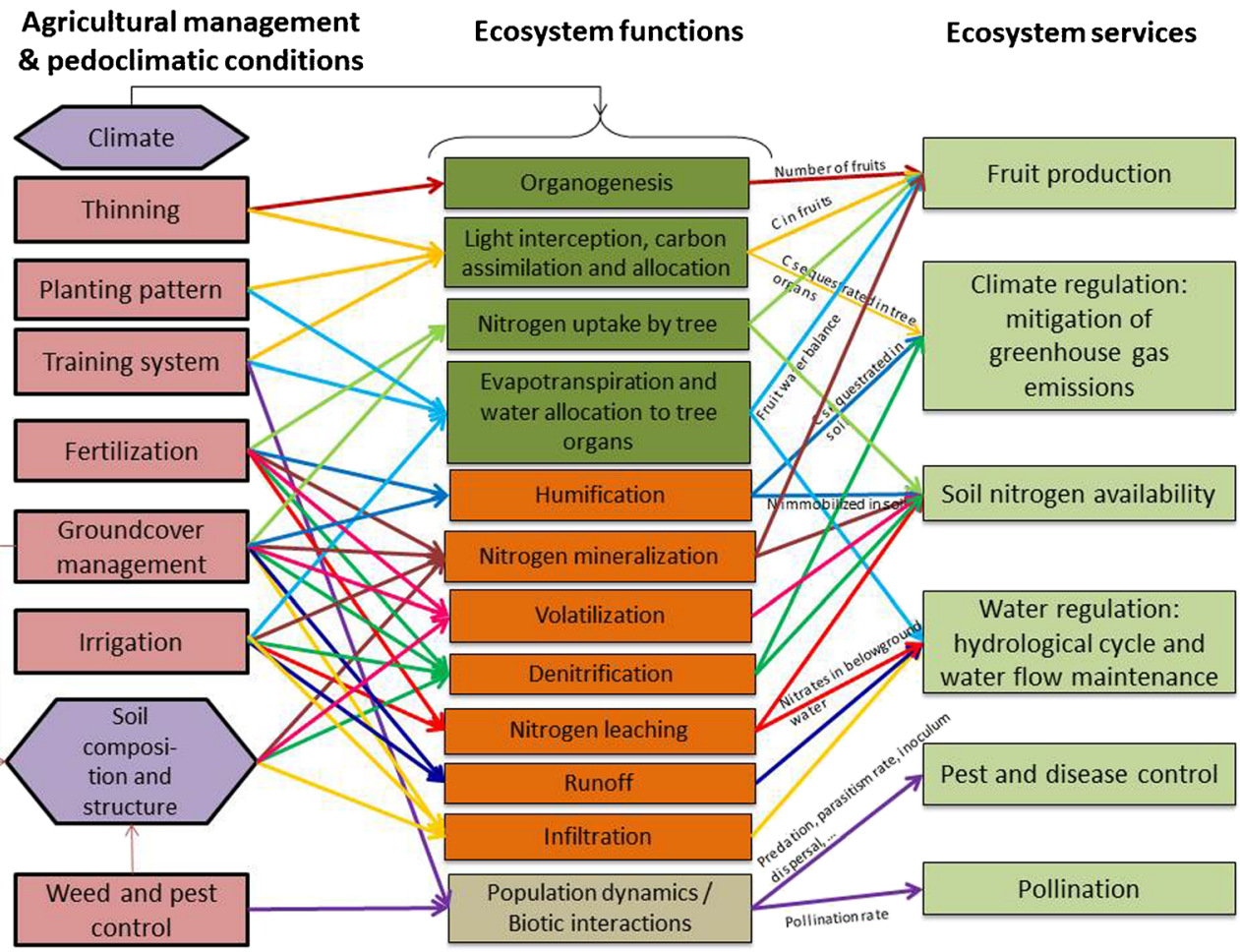




\subsection{Provisioning service: Fruit production in terms of quantity and quality}

Fruit yield is the result of the number of fruits and fruit mass at harvest. Fruit mass and fruit quality result from the fruit growing process, which is mainly driven by carbon. We therefore analyze the fruit production service in terms of organogenesis of fruits and leaves, light interception, carbon assimilation and allocation (Fig. 3). We also consider water and nitrogen effects since nitrogen and water stress may impact fruit yield and quality. Temperature determines the phenology of fruit trees and also impacts crop load and fruit color (Saure 1990), but its effects will not be discussed in detail in this review.

\subsubsection{Organogenesis}

Fruit initiation is a complex process. Under temperate climates, the flower development cycle in fruit trees often lasts from 9 to 10 months, putting flower buds into dormancy between two major activity periods: the appearance of floral primordia in summer and the final flower formation during the following spring. Several factors impact this initiation: endogenous or exogenous hormones and, more specifically, gibberellins, which tend to decrease flower bud formation in alternately bearing apple cultivars, or ecological conditions such as temperature (Koutinas et al. 2010). It is hypothesized that under low light, a reduced number of flower buds are differentiated (Grappadelli 2003). In order to set fruits, compatible pollen grains must be deposited on the stigma. In the case of self-incompatible or dioecious species, pollinizers must be compatible with the cultivar being pollinated and blooming at the same time (Dennis 2003). In this case, the pollination service (Section 2.2.5.) is crucial since pollen is primarily transferred by insects such as honey or bumble bees (Dennis 2003). Agricultural practices such as floral thinning, which may be of interest to reach an optimal number of fruits for yield objectives, may use drying agents that disturb the pollination or fertilization process (Mathieu et al. 2011).

\subsubsection{Light interception, carbon assimilation and allocation}

Light has an immediate effect on the photosynthetic activity of fruit trees since the net total dry matter productivity of apple orchard systems depends on intercepted photosynthetic photon fluxes ranging from 400 to $700 \mathrm{~nm}$ (Wünsche et al. 1996). The most light-efficient apple orchard configurations have been reported as being capable of intercepting $60-70 \%$ of available radiation, which may translate into high yields (Grappadelli 2003) that can reach up to 120 to $140 \mathrm{t} / \mathrm{ha}$ (Lakso et al. 1999) as a theoretical potential. In apple crops, the mean conversion efficiency of light intercepted to grams of fruit ranges from 4 to $6.1 \mathrm{~g} / \mathrm{MJ}$ according to the cultivar, the rootstock as well as the tree training system (Robinson et al.
1993), but values as low as $2 \mathrm{~g} / \mathrm{MJ}$ have been assessed (Robinson et al. 1991).

Planting patterns and training systems are ways of increasing light interception. At the orchard level, a fraction of light does not reach the tree canopy due to the alleyways maintained between rows that make up a large proportion of orchard area uncovered by trees (Jackson and Palmer 1980). Increasing the height of the trees in proportion to the clear alley width helps alleviate this problem since it results in increasing light interception (Grappadelli 2003). More direct means consist in decreasing tree spacing through planting density and changing arrangements since, for example, there is higher light interception with square tree spacing than with rectangular tree spacing (Palmer et al. 1992). Natural training systems used in apple orchards, including centrifugal training (Lauri 2002), may allow good light penetration but require highly developed horticultural skills.

Carbon assimilation and allocation depend on complex source-sink relationships within the tree. Fruits are sinks and the fruit load is important in this respect. A heavy sink load promotes the synthesis of soluble sugars that are readily loaded into the phloem and transported to sink organs (Klages et al. 2001). On the contrary, a low demand for carbon enhances the accumulation of starch, first in leaves and then in roots and other woody tissues (Naschitz et al. 2010), inhibiting photosynthesis. When fruit demand is higher than the potential carbon supply, the competition between fruits is intensified and results in fruit abscission (Zibordi et al. 2009), whereas in the reverse situation, fruit set and growth are favored. However, self-regulatory mechanisms such as natural fruit abscission are usually not sufficient to meet market requirements for fruit size. In many apple-producing areas, early removal of flowers and newly-grown fruits are currently used to reduce competition for photosynthates (Racskó 2006). The severity and timing of thinning are major factors that impact crop load, return bloom and, consequently, fruit size and yield.

The carbon source-sink balance may also impact other fruit quality characteristics. It has been shown that a lower crop load in 'Jonagold' apple cultivar results in a higher content of polyphenols, redder fruit blush, a higher percentage of soluble solids in fruit flesh and better flesh firmness in comparison to fruits from high-cropping trees (Stopar et al. 2002). The crop load strongly impacts carbon allocation between different biochemical compounds and, as a result, the profile of fruit in terms of soluble sugars and acids as shown for peach fruit (Souty et al. 1999; Génard et al. 2008).

\subsubsection{Water and nitrogen effects}

Water stress (deficit of water allocation to tree organs; see Fig. 3) can have serious impacts on carbon assimilation since shoot expansion is almost linearly reduced by declining midday stem water potentials (Lakso 2003). Furthermore, the 
coupled translocation of water and sugars within the tree undeniably links water stress to carbon allocation in fruits (Daudet et al. 2002). A high level of water stress may reduce fruit size and increase the proportion of dry matter in the flesh and, consequently, soluble solids in the fruit. Water stress also tends to increase titrable acidity in ripe fruits, probably through dilution/dehydration effects and osmotic adjustment (Etienne et al. 2013). The timing of water stress is important. Late spring and early summer water stress can have dramatic effects on fruit set and growth (Lakso 2003). Kilili et al. (1996) have shown that withholding irrigation late in the season (104 days after full bloom) improved the quality of 'Braeburn' apple cultivar in terms of increased total soluble solids, firmness, soluble sugars and intensified red skin color without adverse effects on fruit size and yield. These results were confirmed by Mpelasoka et al. (2001).

Irrigation classically seeks to compensate for water stress. The irrigation system is of utmost importance. The root system distribution depends on the spatial distribution of water status in the soil (Sokalska et al. 2009) and it has been shown that under arid conditions, apple roots concentrate under drip emitters, whereas roots of microjet-irrigated trees are more widely distributed over the soil volume (Neilsen et al. 2000). Furthermore, there may be considerable functional variability across the apple root systems (Green and Clothier 1999). In addition, the impact of water stress depends on the rootstock genotype. In apple crops, highly drought tolerant and sensitive rootstocks have been described (Atkinson et al. 1998; Lakso 2003).

Nitrogen is required to support the growth of new tissues. Compared to many other crops, the annual nitrogen requirements of fruit trees are relatively small: in the case of apple trees, $100-120 \mathrm{~kg} \mathrm{~N} / \mathrm{ha}$, for about 45 to $50 \mathrm{t} / \mathrm{ha}$ apples (Greenham 1980; Cheng and Raba 2009). These estimates correspond to whole nitrogen budgets according to the principles of Neilsen and Neilsen (2003). Few studies have been undertaken on fruit tree roots but they suggest that nitrogen supply could vary widely since root length density ranges from 525 to $1234 \mathrm{~m} / \mathrm{m}^{3}$ in apple rootstocks (Ma et al. 2013). Furthermore, nitrogen uptake could be mainly located in the first $20 \mathrm{~cm}$ of soil depth in which the root system seems to be more predominantly distributed (Ma et al. 2013) and where nitrogen mineralization occurs. The rooting densities of apple trees are smaller than those of Poaceae species with which they compete (Neilsen and Neilsen 2002), especially at the interface of tree rows and alleys.

Nitrogen supply may have a positive effect on the carbon source-sink balance and, therefore, on fruit production. As leaf and whole tree photosynthetic capacity is improved by nitrogen supply, the leaf area to fruit ratio increases, leading to more cells per fruit and to larger fruits (Xia et al. 2009).

Concerning soluble sugars in fruit, the accumulation of sugars slightly increases with higher $\mathrm{N}$ supply as a result of the improved supply of carbon to fruit or starch degradation (Xia et al. 2009). According to Raese (1998), repeated applications of mono-ammonium phosphate or N-P-K fertilizers may induce fruit disorders and a lower soil $\mathrm{pH}$, while fertilizers such as calcium nitrate $\left[\mathrm{Ca}\left(\mathrm{NO}_{3}\right)_{2}\right]$ improve fruit color and firmness. High nitrogen application could diminish fruit color and decrease fruit firmness at harvest and during storage since it increases fruit internal ethylene and respiration (Fallahi and Mohan 2000; Fallahi et al. 2002; Xia et al. 2009). System experiments conducted in Washington State (Peck et al. 2006), which compared organic, integrated and conventional cropping systems, showed higher fruit firmness under organic management where the only source of nitrogen was from cover crop legumes. Contradictory effects of nitrogen nutrition on fruit acidity have been reported (Etienne et al. 2013). Regarding nitrogen concentration in fruit, which may be important for apple wine and cider processing (Alberti et al. 2011; Kelkar and Dolan 2012), Toselli et al. (2000) showed a positive effect of nitrogen applied at bloom, probably because fruit in the first stages of its growth successfully competes with other tree organs for nitrogen accumulation.

Nitrogen management must be correctly driven according to nitrogen uptake and to nitrogen reserve remobilization in order to create compromises with possible nitrate water-pollution. Many single-dose or premature spring fertilizer applications may not be efficient if the temperature conditions prohibit nitrate absorption by the roots. Furthermore, during early spring, nitrogen uptake may be inhibited by nitrogen reserve remobilization that occurs at the same time; this makes early application of nitrogen ineffective (Neilsen and Neilsen 2002). In addition, this "extra" nitrogen can easily be leached after a heavy rain (Tagliavini et al. 1996). Agricultural practices such as fertigation may lower the quantity of applied nitrogen compared to broadcast applications (Neilsen and Neilsen 2003), thus contributing to lower leaching (Klein et al. 1989). Other practices such as foliar nitrogen spraying may also have the benefit of controlling the timing of nitrogen supply and potentially reducing the total inputs and losses to the environment since nitrogen is more directly absorbed by leaves.

Regarding the service of fruit production in terms of quantity and quality, the choice of indicators (Table 1) is quite straightforward because standards have been developed for the fruit supply chain and in the horticultural literature. Yield is classically used to describe the production in terms of quantity of any crop in multiple service assessment (Dale and Polasky 2007; Kragt and Robertson 2014; Schipanski et al. 2014; Syswerda and Robertson 2014). The five quality criteria cited below can be assessed at the plot scale using mean values at harvest, given that the spatial variability of fruit quality is large (Génard and Bruchou 1992; Taylor et al. 2007). These criteria cover the concerns of various stakeholders, from fruit growers to consumers. Fruit mass is a convenient proxy 
Table 1 Ecosystem services indicators, units and references

\begin{tabular}{|c|c|c|}
\hline Ecosystem service & Indicator (unit) & References \\
\hline \multirow[t]{6}{*}{ Fruit production } & Fruit mass $(g)$ & \multirow{3}{*}{$\begin{array}{l}\text { Dale and Polasky 2007; Kragt and Robertson 2014; Schipanski } \\
\text { et al. 2014; Syswerda and Robertson } 2014\end{array}$} \\
\hline & Yield (t/ha) & \\
\hline & Size (mm) & \\
\hline & Color grade & Kilili et al. 1996; Mpelasoka et al. 2001; Peck et al. 2006 \\
\hline & $\begin{array}{l}\text { Titratable acidity }(\% \text { of malic acid) } \\
\text { Soluble solids concentration (SSC) }(\%)\end{array}$ & \multirow[t]{2}{*}{$\begin{array}{l}\text { Kilili et al. 1996; Fallahi and Mohan 2000; Mpelasoka et al. } \\
\text { 2001; Peck et al. 2006; Xia et al. } 2009\end{array}$} \\
\hline & Firmness ( $\mathrm{N}$ (newton) or $\mathrm{kg} / \mathrm{cm}^{2}$ ) & \\
\hline \multirow{3}{*}{$\begin{array}{l}\text { Climate regulation } \\
\text { through GHG } \\
\text { mitigation }\end{array}$} & Cumulative denitrified nitrogen $\left(\mathrm{kg} \mathrm{N}_{2} \mathrm{O}-\mathrm{N} / \mathrm{ha} /\right.$ unit time $)$ & Kramer et al. 2006; Groffman et al. 2006 \\
\hline & $\mathrm{C}$ sequestrated in soil and tree $(\mathrm{kg} \mathrm{C} / \mathrm{ha} /$ unit time $)$ & Page et al. 2011; Wu et al. 2012; Zanotelli et al. 2015 \\
\hline & $\begin{array}{l}\text { Cumulative amounts of } \mathrm{CO}_{2} \text { emitted by agricultural } \\
\text { operations }(\mathrm{kg} \mathrm{C} / \mathrm{ha} / \text { unit time })\end{array}$ & Page et al. 2011; Syswerda and Robertson 2014 \\
\hline \multirow[t]{2}{*}{ Soil nitrogen availability } & Soil organic nitrogen variation ( $\mathrm{kg} \mathrm{N} / \mathrm{ha} / \mathrm{unit}$ time) & Quiñones et al. 2007 \\
\hline & $\begin{array}{l}\text { Mean, maximal and minimal soil nitrate concentration } \\
\text { over a time period (mg NO} 3-\mathrm{N} / \mathrm{kg} \text { of dry soil) }\end{array}$ & Glover et al. 2000 \\
\hline \multirow[t]{4}{*}{$\begin{array}{l}\text { Water cycle regulation } \\
\text { and maintenance }\end{array}$} & $\begin{array}{l}\text { Mean water content in different soil depths } \\
\left(\mathrm{g} \mathrm{H}_{2} \mathrm{O} / 100 \mathrm{~g} \text { of dry soil) }\right.\end{array}$ & Syswerda and Robertson 2014 \\
\hline & Water drainage (mm/unit time) & Kragt and Robertson 2014 \\
\hline & Concentration of nitrates in drained water $\left(\mathrm{mg} \mathrm{NO}_{3}-\mathrm{N} / \mathrm{l}\right)$ & Schipanski et al. 2014; Syswerda and Robertson 2014 \\
\hline & Concentration of pesticides in drained water & Loewy et al. 2003; Mottes et al. 2014 \\
\hline \multirow[t]{3}{*}{$\begin{array}{l}\text { Pest and disease } \\
\text { regulation }\end{array}$} & $\begin{array}{l}\text { Rates of predation by natural enemies, rates of parasitism } \\
\text { by parasitoids }\end{array}$ & $\begin{array}{l}\text { Dib et al. 2010; Boreau de Roincé et al. 2013; Maalouly et al. } \\
\text { 2013; Monteiro et al. 2013; Maalouly et al. } 2015\end{array}$ \\
\hline & $\begin{array}{l}\text { Level of injury severity \% fruit loss or \% leaf loss or LAI } \\
\text { loss }\end{array}$ & \\
\hline & $\begin{array}{l}\text { Indicators or models to assess the environmental impact of } \\
\text { pesticides }\end{array}$ & Gutsche and Rossberg 1997; Bockstaller et al. 2008 \\
\hline \multirow[t]{2}{*}{ Pollination } & Abundance and diversity of pollinators & Nicholls and Altieri 2013 \\
\hline & $\begin{array}{l}\text { Number of seeds per fruit } \\
\% \text { of fruit set }\end{array}$ & Volz et al. 1996; Stern et al. 2001; Garratt et al. 2014 \\
\hline
\end{tabular}

because it is both a component of yield and the basis to calculate fruit size and fruit size classes that correspond to market standards. Color grades, titrable acidity and total soluble solids are standard organoleptic criteria widely used for fruit crops (e.g., Ebel et al. 1993; Mills et al. 1994; Mpelasoka et al. 2001; Reganold et al. 2001; Peck et al. 2006). Firmness is used worldwide (e.g., Mpelasoka et al. 2001; Peck et al. 2006) as a gage of ripeness and, therefore, of fruit harvest.

\subsection{Regulation and maintenance services}

\subsubsection{Climate regulation: Mitigation of greenhouse gas emissions}

There are limited references to greenhouse gas emissions and mitigation in orchards in the literature. Denitrification and carbon sequestration in trees and soil, which is a function of carbon assimilation and allocation (Fig. 3), are two important ecosystem functions in this respect. Denitrification is the process by which nitrates are reduced to nitrous oxide $\left(\mathrm{N}_{2} \mathrm{O}\right)$, a greenhouse gas of which $87 \%$ is emitted by agriculture
(CITEPA 2016). Denitrification depends on the physical and chemical conditions of the soil (organic matter, texture, density, $\mathrm{pH}$, temperature and humidity) on climate (rainfall and temperature) and on agricultural practices (Hénault et al. 2013). Consequently, $\mathrm{N}_{2} \mathrm{O}$ emissions are subject to high variability in time and space; at just a few centimeters distance, emissions can vary one-hundred fold. In orchards, irrigation systems such as surface drip irrigation may enhance denitrification because of an anoxic waterlogged bulb created under the distribution tubing. Heavy rains during summer - when soil humidity is already maintained at field capacity - enhance this anoxic waterlogged bulb. This probably explains the higher emissions of $\mathrm{N}_{2} \mathrm{O}$ observed under drip irrigation (1.6 $\pm 0.7 \mathrm{~kg} \mathrm{~N} \mathrm{~N}_{2} \mathrm{O}-\mathrm{N} /$ ha/year) compared to microsprinkler irrigation $\left(0.6 \pm 0.3 \mathrm{~kg} \mathrm{~N} \mathrm{~N}_{2} \mathrm{O}-\mathrm{N} / \mathrm{ha} /\right.$ year $)$ in almond orchards (Alsina et al. 2013). Moreover, it has been shown that subsurface drip irrigation reduced $\mathrm{N}_{2} \mathrm{O}$ emissions compared to surface drip irrigation in olive orchards (Quiñones et al. 2007). Furthermore, cropping systems using legume-based nitrogen inputs generally have lower net $\mathrm{N}_{2} \mathrm{O}$ emissions than cropping systems that rely on synthetic nitrogen fertilizer inputs (Jensen 
et al. 2012). Ammonia fertilizers have a greater positive impact on denitrification than other types of mineral fertilizers (Zhu et al. 2013) and fertigation may increase denitrification (Riga and Charpentier 1999). The production of $\mathrm{N}_{2} \mathrm{O}$ may also be exacerbated by incorporating material with a low $\mathrm{C} / \mathrm{N}$ ratio (Baggs et al. 2000). Since denitrification is promoted by low $\mathrm{O}_{2}$ concentrations that typically occur in wet soils, an increase in macroporosity in the top $50 \mathrm{~mm}$ decreases $\mathrm{N}_{2} \mathrm{O}$ production (Deurer et al. 2009). In orchards, there is experimental evidence that agricultural practices such as the use of cover crops reduce herbicide use or, in the case of organic orchards, that green-waste composts favor soil macroporosity in comparison to conventional orchards where mineral fertilizers, herbicides and drip-irrigation are used (Deurer et al. 2009).

It can be noted that the use of one technique for mitigating $\mathrm{N}_{2} \mathrm{O}$ emissions could jeopardize the mitigation of another GHG emission. For example, using mechanical weeding may increase macroporosity and, as such, decrease $\mathrm{N}_{2} \mathrm{O}$ emissions while at the same time increasing $\mathrm{CO}_{2}$ emissions by using agricultural engines that run on fuel.

Between 400 and 800 Mt. carbon per year could be sequestered worldwide in agricultural soils by implementing appropriate management practices including the increased input of crop residues, reduced tillage and dead wood recycling (IPCC 1995; IPCC 2003). The prevailing opinion is that the contribution of orchards to carbon sequestration is negligible. This opinion refers in large part to the small area that orchards represent in relation to forests and to low tree height in orchards - 3 to $4 \mathrm{~m}$ on average, compared to $15 \mathrm{~m}$ for deciduous forests in temperate regions (Luyssaert et al. 2007). It is nevertheless important to estimate the contribution of orchards, especially in regions where they are highly concentrated. Studies have shown that fruit orchards such as kiwifruit, apple, peach, orange and olive could sequester from 2.4 to $12.5 \mathrm{t}$ C/ha/year (Sofo et al. 2005; Page et al. 2011; Montanaro et al. 2017). Orchards may sequester quantities of carbon similar to those of forests during their first years of life since photosynthesis activity is greater in young trees than in older ones $\mathrm{CWu}$ et al. 2012). In addition, pruning, which is intensively used in orchards, helps increase photosynthesis rates. Furthermore, it has been found that fruit trees have relatively low respiration rates compared to many other plants due to the low construction costs of fruit (in the case of apple trees: Lakso et al. 1999; Zanotelli et al. 2013). This may lead to less carbon loss through respiration in the overall carbon cycle system. Zanotelli et al. (2013) compared the net primary productivity of a natural woody ecosystem of temperate-humid biomes to that of an apple orchard. They showed that the carbon fluxes (gross primary production, net ecosystem productivity and ecosystem respiration) were quantitatively similar in both cases. The organic carbon produced yearly in the whole tree can reach up to $8.54 \mathrm{t} \mathrm{C/ha}$ at harvest. It is allocated to the different apple tree organs as follows: $50 \%$ to fruits, $13 \%$ to leaves - compared to $30 \%$ for deciduous forests, $23 \%$ to aboveground wood, $2 \%$ to belowground wood, and $12 \%$ to fine roots (Zanotelli et al. 2013; Zanotelli et al. 2015). Crop load, planting pattern, training system, rootstock choice and water and nitrogen stress may heavily impact this allocation.

In a carbon balance approach, it is important to consider carbon losses. Mechanical or chemical weeding operations as well as irrigation could increase carbon mineralization in orchard soils, creating carbon loss by heterotrophic respiration of microorganisms. Furthermore, in most cases, carbon in fruit trees is only temporarily sequestered since the lifespan of an orchard ranges from 15 to 30 years and the trees are usually burned without any valorization at the end of their lives. Life cycle analyses show that carbon emissions may also come from other sources: $\mathrm{CO}_{2}$ emissions by engines during weeding or fertilization might represent as much as $23 \%$ of total $\mathrm{CO}_{2}$ emissions in intensive apple orchards (Page et al. 2011). It is therefore important to precisely quantify these losses.

Agricultural management of potentially recyclable elements of orchards such as pruning wood, mowed grasses or senescent leaves (in the 'groundcover management' box in Fig. 3) may help close the carbon biogeochemical cycle. Carbon content and humus production from the decomposition of senescent leaves and pruning material have been measured in young and mature peach and olive orchards. These studies have demonstrated that significant amounts of carbon are sequestered in this way, considering the Mediterranean fruit production surface (Sofo et al. 2005). The use of cover crops, brassica seed meal and especially wood chips increases the quantity of humus in orchard soils, creating carbon storage within the soil. Soil carbon pools have a mean residence time of 12 years for wood chip groundcover (Teravest et al. 2011).

According to the above, indicators of denitrification and carbon sequestration would address the climate regulation service in orchards in a complementary manner (Table 1). Quantification of denitrification is hindered by high spatial and temporal variations (Groffman et al. 2006). Because of this temporal variation, cumulative amounts of denitrified nitrogen over key periods have been proposed for orchards (Kramer et al. 2006). More globally, cumulative amounts of denitrified nitrogen could be used over appropriate time scales, depending on the objective of the study. The most commonly applied method to measure denitrification is based on the ability of acetylene $\left(\mathrm{C}_{2} \mathrm{H}_{2}\right)$ to inhibit the reduction of $\mathrm{N}_{2} \mathrm{O}$ to $\mathrm{N}_{2}$ (Groffman et al. 2006). In the presence of $\mathrm{C}_{2} \mathrm{H}_{2}$, $\mathrm{N}_{2} \mathrm{O}$ becomes the terminal product of denitrification, which can then be quantified by measuring $\mathrm{N}_{2} \mathrm{O}$ production. However, it is now well established that the acetylene inhibition method underestimates denitrification under aerobic incubation conditions (Butterbach-Bahl et al. 2013) and that it is better to use other methods. $\mathrm{N}_{2} \mathrm{O}$ efflux can also be measured using a static chamber method (Folorunso and Rolston 1984; 
Matson et al. 1996). Some denitrification measurements have been made using methods based on labeled ${ }^{15} \mathrm{~N}$ (Myrold 1990). Similarly, the quantities of carbon sequestered in the soil and in different tree organs at specific time scales have been used as indicators in orchards (Page et al. 2011; Wu et al. 2012; Zanotelli et al. 2015). For these measurements, tree excavation is generally required to measure each organ's biomass, and closed gas exchange systems (e.g., Licor photosynthesis system with soil $\mathrm{CO}_{2}$ flux chamber) are necessary to measure $\mathrm{CO}_{2}$ emissions from the soil. Measurement chambers are generally an obstacle to farm machinery. In Zanotelli et al. (2015), soil respiration measurements were therefore conducted in a parallel independent trial. Syswerda and Robertson (2014) used a more sophisticated and data-intensive method that combined these basic indicators and other parameters to calculate a global warming impact. This impact was calculated on a multiannual scale for 20 years by combining the net global warming impact of soil carbon sequestration, agronomic nitrogen fertilizer application, lime application, fuel usage, nitrous oxide emissions and methane $\left(\mathrm{CH}_{4}\right)$ oxidation for each of the studied systems. In view of this type of study, indicators of the direct impact of agricultural practices in terms of $\mathrm{CO}_{2}$ emissions are necessary. Cumulative amounts of $\mathrm{CO}_{2}$ emitted by crop protection products or engines operating in the orchard over the growing season can serve as a simple indicator (Page et al. 2011; Alaphilippe et al. 2013).

\subsubsection{Soil nitrogen availability}

Nitrogen availability for nitrogen uptake by plants is the difference between the inputs of mineral nitrogen, i.e., mineralization of fresh organic matter and humus, fertilization and nitrogen fixation, the losses caused by leaching, volatilization and denitrification, and the immobilization of nitrogen caused by humification (Fig. 3; see Section 2.2.1 for denitrification). These different functions have been extensively described in a generic manner (Calvet 2003; Bot and Benites 2005; White 2006). Regarding orchards, the impact of techniques that act on soil biological activity, which largely contributes to functions that deliver nitrogen, deserves attention. Studies in apple orchards have shown higher biological activity, which is able to enhance mineralization, for organic systems that use cover crops, groundcovers and composts than for conventional ones that use more herbicides and mineral fertilizers (Tagliavini et al. 2007; Hoagland et al. 2008; Teravest et al. 2011). Similarly, the frequent use of cover crops in orchards may significantly increase the abundance and activity of fungi and bacteria that enable humification (Six et al. 2006) since they present high $\mathrm{C} / \mathrm{N}$ ratios. Biological nitrogen fixation by legumes such as white clover (Trifolium repens) in the ground vegetation of orchards may also be a source of nitrogen input to the system. Some figures have placed biological nitrogen fixation in soil within a range of 118 to $126 \mathrm{~kg} \mathrm{~N} / \mathrm{ha}$ over a period of two years in apple orchards, depending on the clover biomass production and ground vegetation management practices (Goh et al. 1995). The difficulty lies in the quantification of the potential nitrogen released from these legumes, especially because other nitrogen cycle functions tend to be inhibitory to symbiotic nitrogen fixation. For example, an excess of nitrate after mineral fertilizer application can create favorable conditions for denitrification (Haynes and Goh 1980), which inhibits nitrogen fixation in the soil.

Soil nitrogen may be loss-driven in fluid forms through leaching. Kramer et al. (2006) placed the amounts of nitrogen leached annually in apple orchards within a range of $68 \mu \mathrm{g}$ of $\mathrm{NO}_{3}-\mathrm{N}$ at a depth of $100 \mathrm{~cm}$ in organic systems, to $1092 \mu \mathrm{g}$ $\mathrm{NO}_{3}-\mathrm{N}$ at a depth of $100 \mathrm{~cm}$ in conventional systems fertilized with calcium nitrate. Managing these disservices is difficult since it is generally the soil texture and structure as well as the climatic conditions that impact nitrogen leaching. However, leaching can be reduced by fractioning nitrogen inputs throughout the year and using cover crops in the alleys. The minimization of nitrogen leaching in orchards must be based on reducing the presence of $\mathrm{NO}_{3}{ }^{-}$ions at the end of the vegetative period (late autumn) since the major risk of water contamination with leaching occurs during winter and in early spring (Tagliavini et al. 1996).

Volatilization occurs when nitrogen is lost in its gaseous form, ammonia. These losses depend on soil conditions $(\mathrm{pH}$, cation exchange capacity, porosity), climatic conditions and type of manure spreading. The percentage of nitrogen lost by volatilization in olive orchards receiving $204 \mathrm{~kg} \mathrm{~N} /$ ha/year was estimated at $1.8 \%$ over 7 days, with much higher losses a few hours after application than a few days later (FernándezEscobar et al. 2012). A proportion of the volatilized nitrogen can be absorbed by the tree, especially by leaves. Boaretto et al. (2013) showed that leaf absorption of ${ }^{15} \mathrm{NH}_{3}$ volatilized from fertilizer was higher in a high planting density system (7\%) than in a standard planting density (3\%) in orange orchards.

Nitrogen "recycling" by leaf and pruned wood restitution to soil makes it possible to close the nitrogen cycle by using the aboveground biomass production. Labeled nitrogen experiments conducted on apple trees showed that the amount of nitrogen derived from leaf litter and taken up by trees over a 2 year period averaged $713 \mathrm{mg}$ nitrogen per tree, which represented $16 \%$ of the nitrogen originally contained in the leaves that had returned to the soil (Tagliavini et al. 2007).

To describe soil nitrogen availability in orchards (Table 1), both soil organic nitrogen content and soil nitrate concentration, which indicate long- and short-term nitrogen availability, respectively, should be considered. In addition, as a matter of principle, dynamics should also be considered. The time window depends on the objective of the study. The detailed dynamics are informative (see Quiñones et al. (2007) for an example in orchards) but they need to be summarized by a 
few statistics for ecosystem service studies. For organic nitrogen content, a variation rate over the chosen time window would be relevant because it describes a balance. For nitrate concentration, minimal, maximal and mean values are classically used to summarize a dynamic series (Glover et al. 2000). Concentrations at key periods of plant development and growth could also be used. Total nitrogen and $\mathrm{NO}_{3}-\mathrm{N}$ soil concentrations in different soil layers are assessed by routine soil analyses in orchards. Alternatively to soil nitrate concentration, simulation studies of multiple ecosystem services in agroecosystems have used nitrogen mineralization as a proxy for plant nitrogen availability. It is the case of Schipanski et al. (2014) who averaged daily values of net nitrogen mineralization over several rotation cycles of annual crops, and of Kragt and Robertson (2014) who used the same proxy on a yearly basis for mixed crop-livestock systems.

\subsubsection{Water regulation: Hydrological cycle and water flow maintenance}

According to the CICES, water regulation services correspond to the capacity to maintain baseline flows for water supply and discharge. As in the case of soil nitrogen budget, the ecosystem functions implied in the classical water balance approach, evapotranspiration, infiltration and runoff (Fig. 3), and their dependence on soil and water conditions, are well known, whereas the characteristics of orchards imply specificities. Evapotranspiration is modified by orchard architecture depending on the planting pattern and the training system, which impact water vapor diffusion resistance (Lakso 2003). Covering trees with nets may impact evapotranspiration (Bastías et al. 2011) in addition to the planting pattern and the training system. Vaissière et al. (2000) showed that the atmospheric relative humidity increases by 1 to $4 \%$ within hail nets. Various operations act on infiltration and runoff. First, in orchards with late cultivars, harvest operations could be detrimental to infiltration because harvest takes place at periods during which the soil can be damp and, therefore, more sensitive to wheel traffic and soil packing. Second, within-row and inter-row soil management are particularly important. In the orchard rows, pre-emergence herbicide use, which is very common, creates bare soil, thus decreasing infiltration and increasing runoff (Merwin et al. 1994). The presence of a groundcover in alleys is a characteristic feature of orchards, although it is not systematic. Oliveira and Merwin (2001) have shown that the infiltration rate was higher on shredded hardwood bark mulch systems since they confer a better floor anchoring and increase permeability through organic matter and macrofauna. In avocado orchards, mixtures of ryegrass and clover increase soil organic matter due to groundcover residues and rhizosphere decomposition (Atucha et al. 2013), thus preventing runoff. However, in mowed grass groundcovers, tractor wheel traffic during mowing could significantly reduce infiltration (Becerra et al. 2010). Nevertheless, it has been reported that groundcovers in orchard alleys decrease yield and tree growth due to nutrient and water competition between grasses and fruit trees (Robinson and O'Kennedy 1978; Atucha et al. 2013). This could be corrected via appropriate fertilization and irrigation management, or by applying a new technique known as the "sandwich", which consists of tilling the soil on both sides of the row while leaving a thin strip of groundcover on the interrow (Schmid and Weibel 2000). The sandwich technique has the advantages of the cover crop in alleys while eliminating the effect of competition from weeds (Garcin et al. 2012). Thus, it may also reduce the reliance on herbicides that has detrimental effects both on soil properties (see above) and on the quality of water at a large scale through runoff.

Decreasing the quantity of water diverted to agriculture, which exceeds $70-80 \%$ of the total in arid and semi-arid zones (Fereres and Soriano 2007), is a key issue. Modern irrigation scheduling concepts have been implemented for this purpose in orchards. Micro-irrigation methods such as micro-aspersion or drip irrigation are frequently used, usually controlled by tensiometers. In limited-water regions, fruit growers are now using techniques that require less water without affecting the functioning of the crop. These techniques, which go under the name of 'regulated deficit irrigation' (Chai et al. 2016), are largely based on a balance between a better use of soil water, more specifically considering the soil water reservoir, together with punctual evapotranspiration reductions at specific stages of tree development.

Classical indicators of hydrological cycle components are available and have been widely adopted (e.g., Pistocchi et al. 2008). Two indicators of the water regulation service are relevant for orchards: drainage and soil water content (Table 1). They are particularly employed in multi-service studies in agroecosystems. Cumulative values of drainage per year have been taken as a proxy for water regulation by Kragt and Robertson (2014). Soil water content, which is indicative of soil water availability for plants, was used by Syswerda and Robertson (2014). As in the case of soil nitrogen availability, seasonal variation should be dealt with using summary statistics or values at key periods that depend on the purpose of the study. Syswerda and Robertson (2014) used soil water content in July, the most water-limited time of the growing season in the conditions of their study. Soil water availability can be monitored by tensiometers that measure the soil water tension (bar) or by capacitance probes that indicate soil water status (in $\mathrm{mm}$ ). In addition to these quantitative components, water quality that can be seriously impaired by the use of fertilizers and pesticides should be considered (Table 1). The concentrations of nitrates and pesticides in drained water could be targeted since they are standard indicators used to control the application of regulation policies such as the Water Framework Directive in Europe. Nitrate concentrations in 
drained water have been used in multi-service studies in agroecosystems (Schipanski et al. 2014; Syswerda and Robertson 2014). In the case of orchards, the autumn period, after fruit harvest, is a relevant time for these concentrations. Nitrogen leaching can be measured by ion exchange resin lysimeters, as described by Susfalk and Johnson (2002), but it remains difficult to evaluate nitrogen leaching at the plot scale.

\subsubsection{Pest and disease control}

The perennial character of orchards poses a great pest management challenge since the various organs of the tree structure provide multiple suitable habitats for arthropod colonization (Beers et al. 2003). At the same time, apple trees host the agents of over 70 infectious diseases (Grove et al. 2003), including bacteria and fungi. These agents cause injuries to the leaves, fruits, branches and twig organs of the tree. In orchards, since most of the production is intended for the fresh product market, damage to fruits is highly prohibitive for future sales and may negatively impact the fruit grower's income. The occurrence and abundance of pests and diseases depends on biotic interactions such as predation, on species' niches and on habitat availability, as well as on dispersal.

The economic value of pest predation is more easily estimated than many other services (Power 2010) since it is possible to directly substitute insecticides with ecosystem services provided by natural enemies. It was estimated that the control of native herbivores by insects led to a savings of 4.49 billion dollars per year in the United States, based on projections of losses that would accrue if insects were not functioning at their current level and assuming that $33 \%$ of pest control is attributable to insects (Losey and Vaughan 2006). In the case of apple orchards, it was estimated that phytoseiid predatory mites and Forficula auricularia eliminate the need for 1-2 acaricide sprays and 2-3 insecticide applications per annum, respectively (Cross et al. 2015). The question is which conditions may favor the control of pests by natural enemies in orchards.

Beneficial insects require plant resources for habitat supply. Plants serving as alternative hosts for a parasitoid or predator of the target crop pest are known as 'banker plants' (Frank 2010). Complex landscapes with a high density and connectivity of uncultivated, perennial habitats that include banker plants have shown an increase in natural enemy populations (Thies 1999). Such landscapes are encountered in orchard areas (Schäckermann et al. 2015). The permanency of the orchard system, which enhances stability and resilience, multi-strata design and the presence of hedgerows, are likely to favor natural enemy populations (Simon et al. 2010). For example, a short groundcover in apple orchard alleys may favor the abundance and predatory behavior of the general predator Forficula pubescens (Marliac et al. 2015). The composition of the groundcover may also have an influence. Flowering plants such as sweet alyssum (Lobularia maritima) have shown a significant attraction potential for natural enemies, leading to the suppression of wooly apple aphid (Eriosoma lanigerum) populations (Gontijo et al. 2013). Wildflower strips are more controversial since some studies have shown encouraging results on aphid predator enhancement using wildflower strips in apple orchards (Wyss 1995; Boller et al. 2004; Pfiffner et al. 2013), while others do not show any significant enhancement of aphid predators (Balzan et al. 2014). Hedgerows, especially mixed ones, have been shown to significantly increase the predation rate by providing shelter to natural enemies (Debras et al. 2011; Miñarro and Prida 2013). The efficiency of phytoseiid predators such as Amblyseius andersoni, Kampimodromus aberrans and Neoseiulus californicus for the regulation of apple red mites (Panonychus ulmi) has been demonstrated in many studies, most of which are reviewed in Ricard et al. (2012). The cessation of acaricide treatments to control red mites preserves these predators, as do semi-natural environments with dense, high and diversified hedges or groves.

Enhancing habitat supply to the natural enemies of pests may be useless if pesticides are still used as a fallback. Pest management is still highly dependent on pesticides in orchards because of strict market quality requirements. Many studies have proven the negative effect of pesticides on natural enemies of pests (Biddinger and Hull 1995; Biddinger et al. 2013; Cumming and Spiesman 2006; Flexner et al. 1986; Pekár 1999). Monteiro et al. (2013) and Vasseur et al. (2013) have shown that pesticides may affect the rate of pest predation within 100-m-wide buffers around the targeted orchard and that drift during pesticide applications may affect natural enemies in the surrounding hedgerows.

Other orchard management practices that consist in introducing 'planned' plant biodiversity may initiate ecological processes linked to the niche and dispersal of pests. This is the case of push stimuli processes that can be performed through companion planting of repellent plants that emit natural chemical substances (Parolin et al. 2012). Cover crops in alleys with aromatic plants such as Centaurea cyanus, Saturela hortensis, and Agerarum houstonianum in pear orchards can reduce the numbers of herbivore pests while increasing the abundance of predators and parasitoids (Song et al. 2010). The choice of aromatic plants to enhance pest control nonetheless requires in-depth research on the aromatic chemical compounds of plants. Other plants known as trap plants are, by definition, more attractive to pests than cultivated crops, thus limiting pests to a particular area where they can be easily controlled by traditional methods (Parolin et al. 2012). They are used in the push-pull strategy of pushing away a pest from a repellent plant and attracting it to the border of the cropped field using trap ("pull") plants (Ratnadass et al. 2012). In addition, fruit trees provide 
resources for pests. Direct modifications of the host plant driven by agricultural practices may help decrease pest populations. For example, in peach orchards, decreasing pruning intensity may lower the degree of green peach aphid (Myzus persicae) infestation due to the decrease in the proportion of growing shoots on which aphids develop much better than on short shoots (Grechi et al. 2008). Similarly, in apple orchards, rosy apple aphid (Dysaphis plantaginea) infestation significantly decreases when the degree of branching, which can be modified by tree training, increases. The underlying hypothesis is that the number of crossroads related to the branching degree affects the probability of reaching the target resource (Simon et al. 2012).

Apple diseases such as apple scab (Venturia inaequalis) and powdery mildew (Podosphaera spp.) may be managed using control methods that could avoid the eight to ten fungicide applications per season (Grove et al. 2003) or more (MAAF, 2014). Genetic control is the most important lever to managing diseases. Many genes that confer resistance to Venturia inaequalis have been identified for apple (Brun et al. 2007). Over 50 scab-resistant cultivars have been released and are gaining in commercial acceptance, while other horticultural characteristics are being simultaneously improved (Grove et al. 2003). A breakdown of the resistance coded by Vf, the most frequently used apple scab resistance gene, has been found (Parisi et al. 1993). This makes it urgent to diversify the sources of resistance to apple scab and to define new breeding strategies.

Mitigating apple scab infection via the plant itself is possible through different agricultural practices. Leaf wetness is important for apple scab, as demonstrated by the fact that leaf wetness duration together with air temperature are used to assess the level of risk of the disease (Mills and LaPlante 1951). Simon et al. (2006) make the hypothesis that training systems such as centrifugal training, which have a positive impact on light interception (Willaume et al. 2004), lead to a higher degree of aeration within the trees, thus shortening the wetness periods that lead to scab infection. Concerning irrigation systems, foliage aspersion can favor foliar wetness, creating ideal conditions for apple scab development and secondary contamination by conidia (Olcott-Reid et al. 1981). Irrigation under foliage is strongly preferred nowadays.

Actions on the inoculum or on the pathogen dispersal enable good control of the apple scab infection. It has been shown that sanitation practices such as leaf litter removal considerably reduce the number of fruit scab lesions at harvest (approximately 70\%) (Gomez et al. 2007), conversely decreasing the food stock for the soil detritus cycle (Zanotelli et al. 2015). Didelot et al. (2007) showed that within-row mixtures of resistant and susceptible cultivars were effective in controlling apple scab because they reduced auto-infection, which is important in the apple tree. Autoinfection is defined as infection caused by a propagule within the same genotype unit. In the case of a within-row mixture, the transmission of apple scab conidia from one tree of a susceptible cultivar to another tree of the same cultivar was limited, on the one hand, by the barrier effect due to the presence of a resistant tree between both and, on the other hand, by the fact that the distance between both was large in relation to the spatial extent of propagule dispersion.

According to these examples, plant and insect biodiversity - as well as agricultural management, which does not necessarily directly target pests but acts via the tree or environmental conditions - enhance ecological pest control. Even though the 'common' strategy still relies on pesticides, fruit growers are becoming aware of these ecological strategies that can be combined in order to optimize pest regulation for low environmental impacts and efficient protection. They constitute an essential element of Integrated Pest Management or IPM (Barzman et al. 2015) that is now mandatory for all crops in the EU member states (European Parliament 2009).

Various indicators of pest and disease control have been proposed in the literature, including in studies of multiple agroecosystem services. Syswerda and Robertson (2014) have used plant diversity to indicate the delivery of biological control and, more generally, arthropod habitat and other conservation benefits. It actually seems that they dealt with plant diversity as a proxy to habitat provision, as in Tsonkova et al. (2014). Schipanski et al. (2014) used lepidopteran and carabid activities as proxies for pest suppression and beneficial insect conservation, respectively. These indicators are fairly distant from the service in question. The same comment applies to the abundance or diversity of natural enemies that has also been used. The enhanced populations of natural enemies in crops provide no guarantee for effective pest control, according to the review of Bianchi et al. (2006). Many studies dealing with insect pest suppression by natural enemies in orchards have considered rates of predation by natural enemies (e.g., Boreau de Roincé et al. 2013; Monteiro et al. 2013; Table 1), rates of parasitism by parasitoids (e.g., Maalouly et al. 2013; Maalouly et al. 2015; Table 1) or rates of parasitism that combine the two processes (e.g., Dib et al. 2010). However, pest suppression is not pest control and there is a need to fill the gap between natural pest control, crop damage and crop yield (Schellhorn et al. 2015). In addition, the abovementioned indicators of pest suppression are less suitable for diseases than for animal pests, and they only deal with topdown effects, excluding bottom-up regulation forces. We propose to alternatively consider fruit, shoot or leaf injury with a degree of cumulative injury severity at harvest (Table 1). This type of indicator can be easily linked to damage at harvest and is commonly used in orchards. It should be noted, however, that in practice, the degree of injury severity may depend not only on the ability of orchards to ecologically control pests and diseases, but also on the action of pesticides. Decoupling these effects is possible experimentally or by modeling, and 
even in observational studies provided that additional indicators such as the level of pesticide use are available. In addition, indicators of the environmental impact of pesticides are necessary. Specific pesticide indicators or ecotoxicological models have been proposed for this purpose (Gutsche and Rossberg 1997; Bockstaller et al. 2008; Table 1).

\subsubsection{Life cycle maintenance: Pollination}

Pollination, the value of which has been estimated at $€ 153$ billion (Gallai et al. 2009), is an essential driving force of crop production. This general statement applies to fruit crops, even though pollination may sometimes be negatively perceived by some stakeholders. This is the case of growers of citrus fruit (particularly tangerine and mandarin orange) in which seeds develop in the case of cross-pollination, whereas seedlessness is an important quality characteristic of these fruits (Sykes 2008; Sagoff 2011).

Many fruit varieties are not self-pollinating. Insect pollination services are provided both by wild, free-living organisms (chiefly bees, but also many butterflies, moths, flies, beetles and wasps), and by commercially managed bee species (primarily the honey bee, Apis mellifera) (Kremen et al. 2007). A minimum of four or five strong colonies per hectare is recommended during the bloom period in mature apple orchards (Dennis 2003). A greater species richness of pollinators may favor fruit set, and apple growers could economically benefit from relying on wild bees for pollination. For example, Osmia cornuta, an alternative pollinator, has a greater tolerance to inclement weather and a higher rate of stigma contact than Apis mellifera in fruit crops (Ladurner et al. 2004).

In orchards, the positive effects of cover crop and hedgerow species richness on the rate of pollination have been demonstrated (Miñarro and Prida 2013; Nicholls and Altieri 2013; Rosa García and Miñarro 2014). This is in accordance with the fact that most pollinator species depend on several floral resources (Miñarro and Prida 2013). The spatial organization of orchards in the landscape in relation to natural habitat is also important since it has been shown that fields situated $1.5 \mathrm{~km}$ away from natural habitat patches can be expected to contain only $50 \%$ of the pollinator diversity of the fields closest to these patches (Ricketts et al. 2008).

Pesticides may impair bee colonies, especially honeybees, in terms of learning performance, behavior and neurophysiology, thus decreasing pollination (Thompson 2003; Desneux et al. 2007). In addition to pesticides, hail nets, which are very common in orchards, may also influence pollination through the decrease in bee colony weight, which is due, in the first place, to forager deaths in the nets and, as a consequence, to swarm death (Vaissière et al. 2000). There is obvious antagonism between pollination and pest regulation through pesticides and exclosure nets, which could be overcome by relying more on biological pest control, as seen in Section 2.2.4.
Indicators of pollination (Table 1) are still in debate (Vaissière, pers. comm.). Similarly to the case of pest and disease control, the pollination value of an agroecosystem can be related to plant diversity. On these bases, Ricou et al. (2014) proposed a vegetation-based indicator of the pollination value of field margin flora using floral traits. The abundance and diversity of pollinators, i.e., of the "service providers", have also largely been highlighted (e.g., Nicholls and Altieri 2013). Although they are not direct indicators of pollination, all these proxies are useful with respect to pollination in the orchard in general, but as far as the fruit trees are concerned, direct indicators that can be measured or modeled could be mobilized. Fruit set and the number of seeds per fruit (for multi-seeded fruits) are common indicators of the efficacy of pollination in orchards (Volz et al. 1996; Stern et al. 2001; Garratt et al. 2014). However, fruit set should be considered with caution and not alone, because pollination is not the only determinant of fruit set.

\section{Assessing and analyzing multiple ecosystem services in orchards}

There are few studies on the assessment of multiple ecosystem services in agroecosystems (Antle and Capalbo 2002; Heal and Small 2002; Lescourret et al. 2015). In the following paragraphs, we propose a two-fold approach to multiple ecosystem service analysis in orchards: using models to quantify indicators of ecosystem services, and exploring their mutual relations.

\subsection{Using models to quantify indicators of ecosystem services and their connections}

As stated above, the relationships between agricultural management, ecosystem functions and ecosystem services present a high degree of complexity. That is why using models can be of great assistance to analyze these relationships. Models can provide a direct quantification of ecosystem service indicators such as those proposed in Section 2, or of indicators of ecosystem functions at a given space and time scale. In addition, they make simulation of changes in ecosystem service profiles and relationships possible according to a large panel of fictive scenarios. There are growing numbers of model-based ecosystem service simulation studies. Thus, Kragt and Robertson (2014) analyzed the impact of various agricultural practices on ecosystem services of farm systems in a maize belt in Western Australia with APSIM, a model that stimulates biophysical processes in a crop-pasture system (Keating et al. 2003). They showed that increasing crop residue retention can jointly increase production value and improve soil carbon and nitrogen supply. Conversely, increasing the use of perennial pastures in the farming mix creates trade-offs between 
production values and non-marketed ecosystem services. Another example is the simulation study of Tsonkova et al. (2014) using a model called the 'Ecosystem Services Assessment Tool for Agroforestry' (ESAT-A), which was designed to compare ecosystem service provision in different agroforestry management situations. According to this simulation study, the provision of habitat, soil fertility, water quality and regulation, and erosion control were greater for alley cropping systems than for conventional agroforestry systems, and within alley cropping systems, the more that poplar tree proportions increased, the higher the provision of ecosystem services was.

STICS, a widely used dynamic model that simulates the soil-crop interactions at a daily time step (Brisson et al. 1998; Brisson et al. 2009), could be a good candidate to represent agricultural production, climate regulation, soil fertility and water cycle regulation in response to agricultural management and pedoclimatic conditions in a unified framework. The main simulated ecosystem processes are crop growth and development, as well as the water and nitrogen balance of the soil-crop system. This model has already been used for ecosystem service analysis. Tribouillois et al. (2016) used STICS to analyze the effect of cover crops and green manuring on leaching and nitrogen fixation, respectively, and then on soil nitrogen availability. The generic character of STICS enables a parameterization of the model to many crops. It has already been parameterized on perennial crops such as grapevine (Vitis vinifera) (Garcia de Cortazar Atauri 2006) and silvergrass (Miscanthus $\times$ Giganteus) (Strullu et al. 2014). However, STICS does not address the question of pests and diseases and their control, and it is necessary to supplement the model or to couple it with pest models to address the set of ecosystem services in Fig. 3.

\subsection{Analyzing multiple ecosystem service relationships}

Ecosystem service relationships are very complex and often non-linear (Lescourret et al. 2015; Rapidel et al. 2015). They are commonly classified as synergies (positive relationships) and trade-offs, also referred to as conflicts (negative relationships). Trade-offs occur when the provision of one ecosystem service is reduced at the expense of another (Rodríguez et al. 2006). Relationships between ecosystem services may be explained by highlighting underlying ecosystem functions and/ or the role of management drivers. Positive ecosystem service relationships may occur when a similar management lever acts on different functions that underpin the services (Bennett et al. 2009). Thus, pest and disease control and soil fertility are not functionally related to each other, but they may respond similarly to groundcover management. Adding organic material to the ground habitat of an apple orchard significantly affects arthropod abundance, leading to more predators and fewer herbivores (Brown and Tworkoski 2004). The physical qualities of mulch can affect apple aphid migration (Damavandian 2000). At the same time, nutrient release from the decomposition of this organic matter can enhance soil quality by increasing soil carbon, nitrogen and microbial biomass (Teravest et al. 2011).

In agroecosystems, agricultural production and regulating services are often in conflict. A conflict may occur when there is a common function, and the challenge is to find a management solution able to mitigate the conflict. For example, in vineyards, intercropping may mitigate runoff but decrease grapevine productivity in the event of competition between intercrops and the grapevine for resources. A simulation study using the VERDI model (Ripoche et al. 2011) suggested that, under irregular rainfall distribution, flexible intercropping management in vineyards can help overcome this trade-off. This flexible management consisted in maintaining cover crops with mowing and possibly destroying them when the available soil water in the field was lower than a reference value. Similarly, Guilpart (2014) studied the link between grapevine yield and regulation of fungal diseases through water stress at flowering. He has shown that decreasing vegetative growth (the common function) could enhance powdery mildew regulation but, at the same time, decrease yield. However, most of the year $n$ yield is determined by year $n-1$ conditions, whereas grapevine vegetative development depends only on year $\mathrm{n}$ conditions. On this basis, he used simulation to show that when specific climatic sequences occur (a wet year followed by a dry year), applying water stress during flowering could reduce vegetative growth without impacting yield, leading to win-win scenarios.

It may be difficult to identify a management lever able to mitigate the conflict between a provisioning and a functionally-linked regulating service in the case of multilever management acting on various functions, which is a very common situation. For example, Grechi et al. (2012) compared crop management strategies using a model of the peach-aphid pathosystem in which, on the one hand, insecticides kill aphids and, on the other, pruning or nitrogen supply impacts the architecture, growth and quality of vegetative organs and, consequently, yield, fruit quality and pest control by acting on aphid dynamics. The effect of insecticides on aphid mortality was evidently predominant, thus obscuring the potential effect of the other cultural methods on the relationship between provisioning and regulating services.

The analysis of two-sided relationships between ecosystem services with a small number of common functions and drivers is obviously limited. Comparing multiple ecosystem service provisioning across different types of agroecosystems generates global information on the way specific crop systems contribute to given profiles of ecosystem services. Syswerda and Robertson (2014) adopted this approach using data of long-term experiments in different cropping systems (annual grain and perennial plants such as alfalfa and hybrid poplar 
trees). They observed that perennial systems made a greater contribution to soil water storage and drainage than annual grains, except for no-till systems, which equally contributed to the provision of these two ecosystem services without losing yield. Within perennial systems, poplar seemed to deliver higher plant species richness than deciduous forests. Among grain systems, biologically-based systems delivered the highest number of ecosystem services in a favorable way, which is in accordance with the findings of Sandhu et al. $(2008,2010)$. Early successional systems were generally favorable to greenhouse gas emission mitigation, while poplar systems presented high provisioning of plant diversity, soil organic matter and nitrate conservation. Significant correlations between several ecosystem services were identified. The most significant positive correlation occurred between drainage and nitrate leaching, and the most negative one was between global warming impact and plant species richness.

\section{Conclusions}

This review demonstrates that orchards represent relevant situations for studies on ecosystem service trade-offs and synergies. Agricultural practices in orchards have a strong impact on several ecosystem functions and, consequently, on ecosystem service relationships. Groundcover management may increase biotic interactions by offering a habitat to natural enemies or repelling crop pests, but it can also avoid runoff and leaching while increasing soil drainage. Pruning may increase fruit production but may favor some pests such as apple aphids as well. Pesticide use remains the most effective pest control method, but its negative impact on ecosystem services such as pollination jeopardizes the sustainability of orchard systems. Irrigation and nitrogen fertilization certainly allow increased fruit production, but they might impact nonmarketed ecosystem services since they have a direct effect on functions like leaching and denitrification.

It should be noted that knowledge gaps that could hamper studies of ecosystem service relationships in orchards exist. Ecosystem services linked to the soil compartment have been studied in annual crop systems, but they remain poorly documented in orchards, in spite of notable exceptions (Montanaro et al. 2017). Measurements on orchards are quite scarce or dispersed, particularly for carbon storage in tree organs and in soil, carbon loss in the atmosphere via respiration rates and $\mathrm{CO}_{2}$ emissions from engines and crop protection products.

In addition, this review did not consider the entire range of ecosystem services and focused on the plot scale. The interested readers can refer to Montanaro et al. (2017) on the maintenance of soil structure and absorption of pollutants in orchards. Cultural services were not considered and are difficult to qualify, but they should not be neglected because fruit trees have esthetic and cultural values (Baumgärtner and Bieri
2006; Montanaro et al. 2017). Cultural services seem to be the poor cousin of ecosystem service assessments (Fagerholm et al. 2016). We have addressed habitat provision, which is important for biodiversity conservation with respect to pest enemies, but this issue may be addressed more globally and at the landscape scale. For instance, it has been shown that modifying the landscape structure by planting fruit trees may enhance the connectivity in various taxa (Baumgärtner and Bieri 2006).

Model-based simulations of a large range of cropping systems provide the foundation for analyzing ecosystem service trade-offs and synergies and for finding the desired combinations of ecosystem services (Rapidel et al. 2015) using multiobjective optimization (Memmah et al. 2015; Ould-Sidi and Lescourret 2011). However, models that consider multiple ecosystem service provision are lacking in the case of orchards. Fruit tree models and fruit tree pest-predator models were designed and used to analyze the effect of cropping systems (Grechi et al. 2012; Lescourret et al. 1999; Lescourret et al. 2010), but they ignored the soil compartment and addressed a limited range of ecosystem services. Therefore, developing more sophisticated orchard models that address multiple ecosystem services and take the impact of soil, climate and agricultural management into account is still a challenge. A similar comment was made by Fagerholm et al. (2016) for agroforestry systems.

The analysis of relationships between agricultural practices and multiple ecosystem services can be useful for the design of innovative orchard systems that optimize the provision of multiple ecosystem services for a large panel of stakeholders. This design will of course require a strong stakeholder involvement (Fagerholm et al. 2016) and imply new social interactions to balance conflicting objectives. Different stakeholders may have different perceptions of services, as exemplified by the case reported about pollination by Sagoff (2011) of apiarists and orange growers, the latter being alarmed by the risks of cross-pollination of oranges by bees. New contracts between social groups have to be established at the regional or local scale. For example, in Baden-Württemberg in Germany, the regional government and non-governmental organizations establish contracts with landowners that determine ways to manage fruit tree meadows in order to qualify for the right to market produce under a specific quality label that generates extra revenue (Thiel et al. 2012). Finally, the collective dimension of multi-service management in areas that include a high density of orchards is a new challenge that opens up new research avenues requiring the cooperation of the ecological and social sciences (Lescourret et al. 2015).

Acknowledgements This study was funded by an industrial training agreement through a CIFRE research fellowship from the CTIFL (Centre Technique Interprofessionnel des Fruits et Légumes) and the 
ANRT (Association Nationale de la Recherche et de la Technologie) on behalf of the French Ministry of Higher Education and Research.

\section{References}

Alaphilippe A, Simon S, Brun L, Hayer F, Gaillard G (2013) Life cycle analysis reveals higher agroecological benefits of organic and lowinput apple production. Agron Sustain Dev 33:581-592. doi:10. 1007/s13593-012-0124-7

Alberti A, Vieira RG, Drilleau JF, Wosiacki G, Nogueira A (2011) Apple wine processing with different nitrogen contents. Brazilian Arch Biol Technol 54:551-558. doi:10.1590/S1516-89132011000300017

Alsina MM, Fanton-Borges AC, Smart DR (2013) Spatiotemporal variation of event related $\mathrm{N} 2 \mathrm{O}$ and $\mathrm{CH} 4$ emissions during fertigation in a California almond orchard. Ecosphere 4:art1. doi:10.1890/ES1200236.1

Andersen L, Kühn BF, Bertelsen M, Bruus M, Larsen SE, Strandberg M (2013) Alternatives to herbicides in an apple orchard, effects on yield, earthworms and plant diversity. Agric Ecosyst Environ 172: 1-5. doi:10.1016/j.agee.2013.04.004

Antle J, Capalbo S (2002) Agriculture as a managed ecosystem: Policy implications. J Agric Resour Econ 27:1-15

Atkinson C, Policarpo M, Webster A, Kuden A (1998) Drought tolerance of apple rootstocks: production and partitioning of dry matter. Plant Soil 206:223-235. doi:10.1023/A:1004415817237

Atucha A, Merwin I, Brown M, Gardiazabal F, Mena F, Adriazola C, Lehmann J (2013) Soil erosion, runoff and nutrient losses in an avocado (Persea americana mill) hillside orchard under different groundcover management systems. Plant Soil 368:393-406. doi: 10.1007/s11104-012-1520-0

Baggs E, Rees R, Smith K, Vinten A (2000) Nitrous oxide emissions from soils after incorporating crop residues. Soil Use Manag 16: $82-87$

Balzan M, Bocci G, Moonen A (2014) Augmenting flower trait diversity in wildflower strips to optimise the conservation of arthropod functional groups for multiple agroecosystem services. J Insect Conserv 18:713-728. doi:10.1007/s10841-014-9680-2

Barzman M, Bàrberi P, Birch A, Boonekamp P, Dachbrodt-Saaydeh S, Graf B, Hommel B, Jensen J, Kiss J, Kudsk P, Lamichhane J, Messéan A, Moonen A, Ratnadass A, Ricci P, Sarah J, Sattin M (2015) Eight principles of integrated pest management. Agron Sustain Dev 35:1199-1215. doi:10.1007/s13593-015-0327-9

Bastías RM, Losciale P, Chieco C, Rossi F, Corelli Grappadelli L (2011) Physiological aspects affected by photoselective nets in apples: preliminary studies. Acta Hortic 907:217-220. doi: 10.17660/ ActaHortic.2011.907.32

Baumgärtner J, Bieri M (2006) Fruit tree ecosystem service provision and enhancement. Ecol Eng 27:118-123. doi:10.1016/j.ecoleng.2005. 12.005

Becerra A, Botta G, Bravo X, Tourn M, Melcon F, Vazquez J, Rivero D, Linares P, Nardon G (2010) Soil compaction distribution under tractor traffic in almond (Prunus amigdalus L.) orchard in Almería España. Soil Tillage Res 107:49-56. doi:10.1016/j.still.2010.02.001

Beers EH, Suckling DM, Prokopy RJ, Avilla J (2003) Ecology and management of apple arthropod pests. In: Ferree D, Warrington IJ (eds) Apples: botany, production and uses. CAB Intern. CABI, Wallingford, pp 489-519

Bennett EM, Peterson GD, Gordon LJ (2009) Understanding relationships among multiple ecosystem services. Ecol Lett 12:13941404. doi:10.1111/j.1461-0248.2009.01387.x

Bianchi F, Booij C, Tscharntke T (2006) Sustainable pest regulation in agricultural landscapes: a review on landscape composition, biodiversity and natural pest control. Proc R Soc Biol Sci 273:1715-1727
Biddinger D, Hull L (1995) Effects of several types of insecticides on the mite predator, Stethorus punctum (Coleoptera: Coccinellidae), including insect growth regulators and abamectin. J Econ Entomol 88:358-366. doi:10.1093/jee/88.2.358

Biddinger D, Robertson J, Mullin C, Frazier J, Ashcraft S, Rajotte E, Joshi N, Vaughn M (2013) Comparative toxicities and synergism of apple orchard pesticides to Apis mellifera (L.) and Osmia cornifrons (Radoszkowski). PLoS One 8:1-6. doi:10.1371/journal. pone. 0072587

Boaretto R, Mattos D, Quaggio J, Cantarella H, Trivelin P (2013) Absorption of $15 \mathrm{NH} 3$ volatilized from urea by citrus trees. Plant Soil 365:283-290. doi:10.1007/s11104-012-1380-7

Bockstaller C, Guichard L, Makowski D, Aveline A, Girardin P, Plantureux S (2008) Agri-environmental indicators to assess cropping and farming systems. A review. Agron Sustain Dev 28: 139-149. doi:10.1051/agro:2007052

Boller EF, Häni F, Poehling H-M (2004) Ecological infrastructures: Ideabook on functional biodiversity at the farm level. Landwirtschaftliche Beratungszentrale Lindau (LBL), Lindau

Bommarco R, Kleijn D, Potts S (2013) Ecological intensification: harnessing ecosystem services for food security. Trends Ecol Evol 28:230-238. doi:10.1016/j.tree.2012.10.012

Boreau de Roincé C, Lavigne C, Mandrin J-F, Rollard C, Symondson WOC (2013) Early-season predation on aphids by winter-active spiders in apple orchards revealed by diagnostic PCR. Bull Entomol Res 103:148-154. doi:10.1017/S0007485312000636

Bot A, Benites J (2005) The importance of soil organic matter. Key to drought-resistant soil and sustained food production. Bull FAO $\mathrm{N}^{\circ}$ 80 89-94.

Brisson N, Launay M, Mary B, Beaudoin N (2009) Conceptual basis, formalisations and parameterization of the STICS crop model. Editions QUAE, Paris

Brisson N, Mary B, Ripoche D, Jeuffroy M, Ruget F, Nicoullaud B, Gate P, Devienne-Barret F, Antonioletti R, Durr C, Guy R, Beaudoin N, Recous S, Tayot X, Plenet D, Cellier P, Machet J-M, Meynard J-M, Delécolle R (1998) STICS: a generic model for the simulation of crops and their water and nitrogen balances. I. Theory and parameterization applied to wheat and corn. Agron Agric Environ 18:311346

Brown M, Tworkoski T (2004) Pest management benefits of compost mulch in apple orchards. Agric Ecosyst Environ 103:465-472. doi:10.1016/j.agee.2003.11.006

Brun L, Didelot F, Parisi L (2007) Stratégies de protection innovantes contre la tavelure du pommier : conception, évaluation et intégration en verger. Innov Agron 1:33-45

Butterbach-Bahl K, Baggs EM, Dannenmann M, Kiese R, ZechmeisterBoltenstern S (2013) Nitrous oxide emissions from soils: how well do we understand the processes and their controls? Philos Trans R Soc B Biol Sci 368:20130122-20130122. doi:10.1098/rstb.2013. 0122

Calvet R (2003) Le sol: propriétés et fonctions. France Agricole Editions, Paris

Chai Q, Gan Y, Zhao C, Xu HL, Waskom RM, Niu Y, Siddique KHM (2016) Regulated deficit irrigation for crop production under drought stress. A review. Agron Sustain Dev 36:1-21. doi:10. 1007/s13593-015-0338-6

Cheng L, Raba R (2009) Accumulation of macro- and micronutrient and nitrogen demand-supply relationship of "Gala"/'Malling 26' apple trees grown in sand culture. J Am Soc Hortic Sci 1:3-13

CITEPA (2016) Rapport National d'Inventaire pour la France au titre de la Convention cadre des Nations Unies sur les Changements Climatiques et du Protocole de Kyoto (CCNUCC). CITEPA, Paris

Codron J, Giraud-Héraud E, Soler L (2005) Minimum quality standards, premium private labels, and European meat and fresh produce retailing. Food Policy 30:270-283. doi:10.1016/j.foodpol.2005.05. 004 
Costanza R, D'Arge R, de Groot R, Farber S (1997) The value of the world's ecosystem services and natural capital. Nature 387:253-260

Cross J, Fountain M, Marko V, Nagy C (2015) Arthropod ecosystem services in apple orchards and their economic benefits. Ecol Entomol 40:82-96. doi:10.1111/een.12234

Cumming G, Spiesman B (2006) Regional problems need integrated solutions: Pest management and conservation biology in agroecosystems. Biol Conserv 131:533-543. doi:10.1016/j.biocon. 2006.02.025

Daily G (1997) Nature's services. Societal dependence on natural ecosystems. Island Press, Washington DC

Dale V, Polasky S (2007) Measures of the effects of agricultural practices on ecosystem services. Ecol Econ 64:286-296. doi:10.1016/j. ecolecon.2007.05.009

Damavandian M (2000) Biology of subterranean populations of woolly apple aphid, Eriosoma Lanigerum (Hausmann) (Homoptera: Aphididae), in apple orchards. PhD. University of Stellenbosch, South Africa

Daudet FA, Lacointe A, Gaudillère JP, Cruiziat P (2002) Generalized Münch coupling between sugar and water fluxes for modelling carbon allocation as affected by water status. J Theor Biol 214:481498. doi:10.1006/jtbi.2001.2473

de Groot R, Alkemade R, Braat L, Hein L, Willemen L (2010) Challenges in integrating the concept of ecosystem services and values in landscape planning, management and decision making. Ecol Complex 7: 260-272. doi:10.1016/j.ecocom.2009.10.006

Debras JF, Senoussi R, Dutoit T (2011) Hedgerow effects on the distribution of beneficial arthropods in a pear orchard in southern France. Ecol Mediterr 37:75-83

Dennis F (2003) Flowering, pollination and fruit set and development. In: Ferree DC, Warrington IJ (eds) Apples: botany, production and uses. CABI, Wallingford, pp 153-166

Desneux N, Decourtye A, Delpuech J (2007) The sublethal effects of pesticides on beneficial arthropods. Annu Rev Entomol 52:81106. doi:10.1146/annurev.ento.52.110405.091440

Deurer M, Grinev D, Young I, Clothier B, Müller K (2009) The impact of soil carbon management on soil macropore structure: a comparison of two apple orchard systems in New Zealand. Eur J Soil Sci 60: 945-955. doi:10.1111/j.1365-2389.2009.01164.x

Dib H, Simon S, Sauphanor B, Capowiez Y (2010) The role of natural enemies on the population dynamics of the rosy apple aphid, Dysaphis Plantaginea Passerini (Hemiptera: Aphididae) in organic apple orchards in south-eastern France. Biol Control 55:97-109. doi:10.1016/j.biocontrol.2010.07.005

Didelot F, Brun L, Parisi L (2007) Effects of cultivar mixtures on scab control in apple orchards. Plant Pathol 56:1014-1022. doi:10.1111/j. 1365-3059.2007.01695.x

Ebel RC, Proebsting EL, Patterson ME (1993) Regulated deficit irrigation may Alter apple maturity, quality, and storage life. Hortscience 28: $141-143$

Etienne A, Génard M, Lobit P, Mbeguié-A-Mbéguié D, Bugaud C (2013) What controls fleshy fruit acidity? A review of malate and citrate accumulation in fruit cells. J Exp Bot 64:1451-1469. doi:10.1093/ jxb/ert035

European Parliament (2009) Directive 2009/128/EC of the European Parliament and of the Council of 21 October 2009 establishing a framework for Community action to achieve the sustainable use of pesticides.

Fagerholm N, Torralba M, Burgess PJ, Plieninger T (2016) A systematic map of ecosystem services assessments around European agroforestry. Ecol Indic 62:47-65. doi:10.1016/j.ecolind.2015.11.016

Fallahi E, Khemira H, Righetti TL, Azarenko AN (2002) Influence of foliar application of urea on tree growth, fruit quality, leaf minerals and distribution of urea-drived nitrogen in apples. Acta Hortic 594: 603-610
Fallahi E, Mohan SK (2000) Influence of nitrogen and rootstock on tree growth, precocity, fruit quality, leaf mineral nutrients, and fire blight in "scarlet Gala" apple. HortTechnology 10:589-592

Fereres E, Soriano M (2007) Deficit irrigation for reducing agricultural water use. J Exp Bot 58:147-159. doi:10.1093/jxb/er1165

Fernández-Escobar R, García-Novelo JM, Molina-Soria C, Parra MA (2012) An approach to nitrogen balance in olive orchards. Sci Hortic (Amsterdam) 135:219-226. doi:10.1016/j.scienta.2011.11. 036

Flexner J, Lighthart B, Croft B (1986) The effects of microbial pesticides on non-target, beneficial arthropods. Agric Ecosyst Environ 16: 203-254. doi:10.1016/0167-8809(86)90005-8

Floch C, Capowiez Y, Criquet S (2009) Enzyme activities in apple orchard agroecosystems: how are they affected by management strategy and soil properties. Soil Biol Biochem 41:61-68. doi:10.1016/j. soilbio.2008.09.018

Folorunso OA, Rolston DE (1984) Spatial variability of field-measured denitrification gas fluxes. Soil Sci Soc Am J 48:1214-1219. doi:10. 2136/sssaj1984.03615995004800060002x

Frank SD (2010) Biological control of arthropod pests using banker plant systems: past progress and future directions. Biol Control 52:8-16. doi:10.1016/j.biocontrol.2009.09.011

Gallai N, Salles J, Settele J, Vaissière B (2009) Economic valuation of the vulnerability of world agriculture confronted with pollinator decline. Ecol Econ 68:810-821. doi:10.1016/j.ecolecon.2008.06.014

García-Nieto A, García-Llorente M, Iniesta-Arandia I, Martín-López B (2013) Mapping forest ecosystem services: from providing units to beneficiaries. Ecosyst Serv 4:126-138. doi:10.1016/j.ecoser.2013. 03.003

Garcia de Cortazar Atauri I (2006) Adaptation du modèle STICS à la vigne (Vitis vinifera L.). Utilisation dans le cadre d'une étude d'impact du changement climatique à l'échelle de la France. $\mathrm{PhD}$. Ecole Nationale Supérieure Agronomique, Montpellier

Garcin A, Bussi C, Corroyer N, Dupont N, Ondet S, Parveaud C (2012) Alternatives au travail du sol sur le rang et gestion du sol en arboriculture. Alter Agri 116:19-21

Garratt MPD, Truslove CL, Coston DJ, Evans RL, Moss ED, Dodson C, Jenner N, Biesmeijer JC, Potts SG (2014) Pollination deficits in UK apple orchards. J Pollinat Ecol 12:9-14

Geiger F, Bengtsson J, Berendse F, Weisser W, Emmerson M, Morales M, Ceryngier P, Liira J, Tscharntke T, Winqvist C, Eggers S, Bommarco R, Pärt T, Bretagnolle V, Plantegenest M, Clement L, Dennis C, Palmer C, Oñate J, Guerrero I, Hawro V, Aavik T, Thies C, Flohre A, Hänke S, Fischer C, Goedhart P, Inchausti P (2011) Persistent negative effects of pesticides on biodiversity and biological control potential on European farmland. Basic Appl Ecol 12:386-387. doi: 10.1016/j.baae.2011.03.004

Génard M, Bruchou C (1992) Multivariate analysis of within-tree factors accounting for the variation of peach fruit quality. Sci Hortic (Amsterdam) 52:37-51. doi:10.1016/0304-4238(92)90006-X

Génard M, Dauzat J, Franck N, Lescourret F, Moitrier N, Vaast P, Vercambre $G$ (2008) Carbon allocation in fruit trees: from theory to modelling. Trees-Struct Funct 22:269-282. doi:10.1007/s00468007-0176-5

Glover JD, Reganold JP, Andrews PK (2000) Systematic method for rating soil quality of conventional, organic, and integrated apple orchards in Washington state. Agric Ecosyst Environ 80:29-45. doi:10.1016/S0167-8809(00)00131-6

Goh K, Ridgen G, Daly M (1995) Understorey biomass production and biological nitrogen fixation in an organic apple orchard in Canterbury, New Zealand. Commun Soil Sci Plant Anal 26:32613273

Gomez C, Brun L, Chauffour D, Vallée D, De Le Vallée D (2007) Effect of leaf litter management on scab development in an organic apple orchard. Agric Ecosyst Environ 118:249-255. doi:10.1016/j.agee. 2006.05.025 
Gontijo L, Beers E, Snyder W (2013) Flowers promote aphid suppression in apple orchards. Biol Control 66:8-15. doi:10.1016/j.biocontrol. 2013.03.007

Grappadelli LC (2003) Light relations. In: Ferree DC, Warrington IJ (eds) Apples: botany, production and uses. CABI, Wallingford, pp 195216

Grechi I, Ould-Sidi M, Hilgert N, Senoussi R, Sauphanor B, Lescourret F (2012) Designing integrated management scenarios using simulation-based and multi-objective optimization: application to the peach tree-Myzus persicae Aphid system. Ecol Model 246:4759. doi:10.1016/j.ecolmodel.2012.07.023

Grechi I, Sauge M, Sauphanor B, Hilgert N, Senoussi R, Lescourret F (2008) How does winter pruning affect peach tree-Myzus persicae interactions? Entomol Exp Appl 128:369-379. doi:10.1111/j.15707458.2008.00720.x

Green S, Clothier B (1999) The root zone dynamics of water uptake by a mature apple tree. Plant Soil 206:61-77. doi:10.1023/A: 1004368906698

Greenham D (1980) Nutrient cycling: the estimation of orchard nutrient uptake. In: Atkinson D, Jackson JE, Sharples RO, Waller WM (eds) Mineral nutrition of fruit trees. Butterworths, Sevenoaks, pp 345352

Groffman PM, Altabet MA, Böhlke JK, Butterbach-Bahl K, David MB, Firestone MK, Giblin AE, Kana TM, Nielsen LP, Voytek MA (2006) Methods for measuring denitrification: diverse approaches to a difficult problem. Ecol Appl 16:2091-2122

Grove GG, Eastwell KC, Jones AL, Sutton TB (2003) Diseases of apple. In: Ferree DC, Warrington IJ (eds) Apples: botany, production and uses. CABI, Wallingford, pp 459-488

Guilpart N (2014) Relations entre services écosystémiques dans un agroécosystème à base de plantes pérennes : compromis entre rendement de la vigne et régulation de l'oïdium. $\mathrm{PhD}$. Montpellier SupAgro

Gutsche V, Rossberg D (1997) SYNOPS 1.1: a model to assess and to compare the environmental risk potential of active ingredients in plant protection products. Agric Ecosyst Environ 64:181-188

Haines-Young R, Potschin M (2009) Methodologies for defining and assessing ecosystem services. Final Report, JNCC, Proj Code C08-0170-0062 $69 \mathrm{pp}$

Haines-Young R, Potschin M (2013) Common International Classification of Ecosystem Services (CICES): Consultation on version 4, August-December 2012. EEA Framework contract No EEA/ IEA/09/003

Haynes R, Goh K (1980) Distribution and budget of nutrient in a commercial apple orchard. Plant Soil 56:445-457

Heal G, Small A (2002) Agriculture and its external linkages. In: Gardner B, Rausser G (eds) Handbook of agricultural economics: volume 2A. Elsevier, Amsterdam, pp 1342-1369

Hénault C, Rochette P, Kuikman P, Flénet F, Cellier P (2013) Le protoxyde d'azote (N2O), puissant gaz à effet de serre émis par les sols agricoles: méthodes d'inventaire et leviers de réduction. OCL 20:108-118

Hoagland L, Carpenter-Boggs L, Granatstein D, Mazzola M, Smith J, Peryea F, Reganold J (2008) Orchard floor management effects on nitrogen fertility and soil biological activity in a newly established organic apple orchard. Biol Fertil Soils 45:11-18. doi:10.1007/ s00374-008-0304-4

IPCC (1995) Climate change 1995. Cambridge University Press, The science of climate change

IPCC (2003) Intergovernmental Panel on Climate Change. Good practice guidance for land use, land-use change and forestry. Institute for Global Environmental Strategies (IGES), Hayama

Jackson JE, Palmer JW (1980) A computer model study of light interception by orchards in relation to mechanised harvesting and management. Sci Hortic (Amsterdam) 13:1-7
Jensen E, Peoples M, Boddey R, Gresshoff P, Henrik H, Alves B, Morrison M (2012) Legumes for mitigation of climate change and the provision of feedstock for biofuels and biorefineries. A review. Agron Sustain Dev 32:329-364. doi:10.1007/s13593-011-0056-7

Keating B, Carberry P, Hammer G, Probert M, Robertson M, Holzworth D, Huth NI, Hargreaves J, Meinke H, Hochman Z, McLean G, Verburg K, Snow V, Dimes J, Silburn M, Wang E, Brown S, Bristow K, Asseng S, Chapman S, McCown R, Freebairn D, Smith C (2003) An overview of APSIM, a model designed for farming systems simulation. Eur J Agron 18:267-288. doi:10. 1016/S1161-0301(02)00108-9

Kelkar S, Dolan K (2012) Modeling the effects of initial nitrogen content and temperature on fermentation kinetics of hard cider. J Food Eng 109:588-596. doi:10.1016/j.jfoodeng.2011.10.020

Kilili A, Behboudian M, Mills T (1996) Composition and quality of "Braeburn" apples under reduced irrigation. Sci Hortic (Amsterdam) 67:1-11. doi:10.1016/S0304-4238(96)00939-9

Klages K, Donnison H, Wünsche J, Boldingh H (2001) Diurnal changes in non-structural carbohydrates in leaves, phloem exudate and fruit in "Braeburn" apple. Funct Plant Biol 28:131-139

Klein I, Levin I, Assaf R, Berkovitz A (1989) Drip nitrogen fertigation of ' Starking Delicious' apple trees. Plant Soil 119:305-314. doi:10. 1007/BF02370423

Koutinas N, Pepelyankov G, Lichev V (2010) Flower induction and flower bud development in apple and sweet cherry. Biotechnol Biotechnol Equip 24:1549-1558. doi:10.2478/V10133-010-0003-9

Kragt ME, Robertson MJ (2014) Quantifying ecosystem services tradeoffs from agricultural practices. Ecol Econ 102:147-157. doi:10. 1016/j.ecolecon.2014.04.001

Kramer S, Reganold J, Glover J, Bohannan B, Mooney H (2006) Reduced nitrate leaching and enhanced denitrifier activity and efficiency in organically fertilized soils. Proc Natl Acad Sci U S A 103: 4522-4527. doi:10.1073/pnas.0600359103

Kremen C, Williams N, Aizen M, Gemmill-Herren B, LeBuhn G, Minckley R, Packer L, Potts S, Roulston T, Steffan-Dewenter I, Vázquez D, Winfree R, Adams L, Crone E, Greenleaf S, Keitt T, Klein A, Regetz J, Ricketts T (2007) Pollination and other ecosystem services produced by mobile organisms: a conceptual framework for the effects of land-use change. Ecol Lett 10:299-314. doi: 10.1111/j.1461-0248.2007.01018.x

Krieger D (2001) The economic value of Forest ecosystem Services : a review. Wilderness Soc:1-31

Ladurner E, Recla L, Wolf M, Zelger R, Burgio G (2004) Osmia cornuta (hymenoptera Megachilidae) densities required for apple pollination : a cage study. J Apic Res 43:118-122. doi:10.1080/ 00218839.2004 .11101121

Lakso A, Wünsche J, Palmer J, Corelli Grappadelli L (1999) Measurement and modeling of carbon balance of the apple tree. Hortscience 34:1040-1047

Lakso AN (2003) Water relations of apples. In: Ferree D, Warrington IJ (eds) Apples: botany, production and uses. CABI, Wallingford, pp 167-194

Lauri P (2002) From tree architecture to tree training - an overview of recent concepts developed in apple in France. J Korean Soc Hortic Sci 43:782-788

Lescourret F, Blecher N, Habib R, Chadoeuf J, Agostini D, Pailly O, Vaissière B, Poggi I (1999) Development of a simulation model for studying kiwi fruit orchard management. Agric Syst 59:215239. doi:10.1016/S0308-521X(99)00006-2

Lescourret F, Magda D, Richard G, Adam-Blondon A, Bardy M, Baudry J, Doussan I, Dumont B, Lefèvre F, Litrico I, Martin-Clouaire R, Montuelle B, Pellerin S, Plantegenest M, Tancoigne E, Thomas A, Guyomard H, Soussana J (2015) A social-ecological approach to managing multiple agro-ecosystem services. Curr Opin Environ Sustain 14:68-75. doi:10.1016/j.cosust.2015.04.001 
Lescourret F, Moitrier N, Valsesia P, Génard M (2010) QualiTree, a virtual fruit tree to study the management of fruit quality. I Model development Trees 25:519-530. doi:10.1007/s00468-010-0531-9

Loewy R, Carvajal L, Novelli M, Pechen de D'Angelo A (2003) Effect of pesticide use in fruit production orchards on shallow ground water. $\mathrm{J}$ Environ Sci Heal Part B 38:317-325

Losey J, Vaughan M (2006) The economic value of ecological services provided by insects. Bioscience 56:311-323

Luyssaert S, Inglima I, Jung M, Richardson A, Reichstein M, Papale D, Piao S, Schulze E, Wingate L, Matteucci G (2007) CO2 balance of boreal, temperate, and tropical forests derived from a global database. Glob Chang Biol 13:2509-2537. doi:10.1111/j.1365-2486. 2007.01439.x

Ma L, Hou C, ZHang X, Li H, Han D, Wang Y (2013) Seasonal growth and spatial distribution of apple tree roots on different rootstocks or Interstems. J Am Soc Hortic Sci 138:79-87

MAAF (2014) Enquête pratiques phytosanitaires en arboriculture. Agreste les Dossiers 22:1-17

Maalouly M, Franck P, Bouvier JC, Toubon JF, Lavigne C (2013) Codling moth parasitism is affected by semi-natural habitats and agricultural practices at orchard and landscape levels. Agric Ecosyst Environ 169:33-42. doi:10.1016/j.agee.2013.02.008

Maalouly M, Franck P, Lavigne C (2015) Temporal dynamics of parasitoid assemblages parasitizing the codling moth. Biol Control 82:3139. doi:10.1016/j.biocontrol.2014.11.013

Marliac G, Simon S, Mazzia C, Penvern S, Lescourret F, Capowiez Y (2015) Increased grass cover height in the alleys of apple orchards does not promote Cydia pomonella biocontrol. BioControl 60:805815. doi:10.1007/s10526-015-9687-y

Mathieu V, Lavoisier C, Ferre G (2011) L'éclaircissage du pommier. Editions Ctifl, Paris

Matson P, Billow C, Hall S, Zachariassen J (1996) Fertilization practices and soil variations control nitrogen oxide emissions from tropical sugar cane. J Geophys Res 101:533-545. doi:10.1029/96JD01536

Memmah M, Lescourret F, Yao X, Lavigne C (2015) Metaheuristics for agricultural land use optimization. A review. Agron Sustain Dev 35: 975-998. doi:10.1007/s13593-015-0303-4

Merwin IA, Stiles WC, van Es HM (1994) Orchard groundcover management impacts on soil physical properties. J Am Soc Hortic Sci 119:216-222

Mills TM, Behboudian MH, Tan PY, Clothier BE (1994) Plant water status and fruit quality in Braeburn'apples. Hortscience 29:12741278

Mills WD, LaPlante AA (1951) Diseases and insects in the orchard. Cornell Extension Bulletin, In

Miñarro M, Prida E (2013) Hedgerows surrounding organic apple orchards in north-west Spain: potential to conserve beneficial insects. Agric For Entomol 15:382-390. doi:10.1111/afe.12025

Monteiro L, Lavigne C, Ricci B, Frank P, Toubon J, Sauphanor B (2013) Predation of codling moth eggs is affected by pest management practices at orchard and landscape levels. Agric Ecosyst Environ 166:86-93. doi:10.1016/j.agee.2011.10.012

Montanaro G, Xiloyannis C, Nuzzo V, Dichio B (2017) Orchard management, soil organic carbon and ecosystem services in Mediterranean fruit tree crops. Sci Hortic 217:92-101. doi:10. 1016/j.scienta.2017.01.012

Mottes C, Lesueur-Jannoyer M, Le Bail M, Malézieux E (2014) Pesticide transfer models in crop and watershed systems: a review. Agron Sustain Dev 34:229-250. doi:10.1007/s13593-013-0176-3

Mpelasoka BS, Behboudian MH, Green SR (2001) Water use, yield and fruit quality of lysimeter-grown apple trees: responses to deficit irrigation and to crop load. Irrig Sci 20:107-113. doi:10.1007/ s002710100041

Myrold DD (1990) Measuring denitrification in soils using $15 \mathrm{~N}$ techniques. In: Revsbech NP, Sørensen J (eds) Denitrification in soil and sediment. Springer US, Boston, MA, pp 181-198
Naschitz S, Naor A, Genish S, Wolf S, Goldschmidt E (2010) Internal management of non-structural carbohydrate resources in apple leaves and branch wood under a broad range of sink and source manipulations. Tree Physiol 30:715-727. doi:10.1093/treephys/ tpq028

Neilsen D, Neilsen GH (2002) Efficient use of nitrogen and water in highdensity apple orchards. HortTechnology 12:19-25

Neilsen GH, Neilsen D (2003) Nutritional requirements of apple. In: Ferree DC, Warrington IJ (eds) Apples: botany, production and uses. CABI, Wallingford, pp 267-302

Neilsen GH, Parchomchuk P, Neilsen D, Zebarth BJ (2000) Dripfertigation of apple trees affects root distribution and development of K deficiency. Can J Soil Sci 80:353-361

Nicholls C, Altieri M (2013) Plant biodiversity enhances bees and other insect pollinators in agroecosystems. A review. Agron Sustain Dev 33:257-274. doi:10.1007/s13593-012-0092-y

Olcott-Reid B, Sutton TB, Unrath C (1981) Evaporative cooling irrigation influences disease, insect, and mite pests of "Delicious" apples. J Am Soc Hortic Sci 106:469-474

Oliveira M, Merwin I (2001) Soil physical conditions in a New York orchard after eight years under different groundcover management systems. Plant Soil 234:233-237. doi:10.1023/A:1017992810626

Ould-Sidi M, Lescourret F (2011) Model-based design of integrated production systems: a review. Agron Sustain Dev 31:571-588. doi:10. 1007/s13593-011-0002-8

Page G, Kelly T, Minor M, Cameron E (2011) Modeling carbon footprints of organic orchard production systems to address carbon trading: an approach based on life cycle assessment. Hortscience 46: 324-327

Palmer JW, Avery DJ, Wertheim SJ (1992) Effect of apple tree spacing and summer pruning on leaf area distribution and light interception. Sci Hortic (Amsterdam) 52:303-312. doi:10.1016/0304-4238(92) 90031-7

Parisi L, Lespinasse Y, Guillaume J, Krüger J, Guillaumes J, Krüger J (1993) A new race of Venturia inaequalis virulent to apples with resistance due to the Vf Gene. Phytopathology 83:533-537. doi: 10.1094/Phyto-83-533

Parolin P, Bresch C, Desneux N, Brun R, Bout A, Boll R, Poncet C (2012) Secondary plants used in biological control: a review. Int $\mathbf{J}$ Pest Manag 58:91-100. doi:10.1080/09670874.2012.659229

Peck G, Andrews P, Reganold J, Fellman J (2006) Apple orchard productivity and fruit quality under organic, conventional, and integrated management. Hortscience 41:99-107

Pekár S (1999) Effect of IPM practices and conventional spraying on spider population dynamics in an apple orchard. Agric Ecosyst Environ 73:155-166. doi:10.1016/S0167-8809(99)00024-9

Pfiffner L, Scharer H, Luka H (2013) Functional biodiversity to improve pest control in organic cropping systems. In: Korean organic conference, 25th October. Suwon, Korea,

Pistocchi A, Bouraoui F, Bittelli M (2008) A simplified parameterization of the monthly topsoil water budget. Water Resour Res 44:0. doi:10. 1029/2007WR006603

Power AG (2010) Ecosystem services and agriculture: tradeoffs and synergies. Philos Trans R Soc B Biol Sci 365:2959-2971. doi:10.1098/ rstb. 2010.0143

Quiñones A, Martínez-Alcántara B, Legaz F (2007) Influence of irrigation system and fertilization management on seasonal distribution of $\mathrm{N}$ in the soil profile and on $\mathrm{N}$-uptake by citrus trees. Agric Ecosyst Environ 122:399-409. doi:10.1016/j.agee.2007.02.004

Racskó J (2006) Crop load, fruit thinning and their effects on fruit quality of apple ( Malus domestica Borkh.) J Agric Sci 24:29-35

Raese J (1998) Response of apple and pear trees to nitrogen, phosphorus, and potassium fertilizers. J Plant Nutr 21:2671-2696. doi:10.1080/ 01904169809365597

Rapidel B, Ripoche A, Allinne C, Metay A, Deheuvels O, Lamanda N, Blazy J-M, Valdés-Gómez H, Gary C (2015) Analysis of ecosystem 
services trade-offs to design agroecosystems with perennial crops. Agron Sustain Dev 35:0. doi:10.1007/s13593-015-0317-y

Ratnadass A, Fernandes P, Avelino J, Habib R (2012) Plant species diversity for sustainable management of crop pests and diseases in agroecosystems: a review. Agron Sustain Dev 32:273-303. doi:10. 1007/s13593-011-0022-4

Reganold JP, Glover JD, Andrews PK, Hinman HR (2001) Sustainability of three apple production systems. Nature 410:926-930. doi:10. 1038/nature 05188

Reid W, Mooney H, Cropper A, Capistrano D, Carpentier S, Chopra K, Dasgupta P, Dietz T, Duraiappah A, Hassan R, Kasperson R, Leemans R, May R, McMichael A, Pingali P, Samper C, Scholes R, Watson R, Zakri A, Shidong Z, Ash N, Bennett J, Kumar P, Lee M, Raudsepp-Hearne C, Simons H, Thonell J, Zurek N (2005) Ecosystems and human well-being: synthesis. Millenium ecosystem assessment. Island Press, Washington DC

Ricard J, Garcin A, Jay M, Mandrin J (2012) Biodiversité et régulation des ravageurs en arboriculture fruitière. Editions Ctifl, Paris

Ricketts T, Regetz S-DI, Cunningham S, Kremen C, Bogdanski A, Gemmill-Herren B, Greenleaf S, Klein A, Mayfield M, Morandin L, Ochieng A, Viana B (2008) Landscape effects on crop pollination services: are there general patterns? Ecol Lett 11:499-515. doi:10. 1111/j.1461-0248.2008.01157.x

Ricou C, Schneller C, Amiaud B, Plantureux S, Bockstaller C (2014) A vegetation-based indicator to assess the pollination value of field margin flora. Ecol Indic 45:320-331. doi:10.1016/j.ecolind.2014. 03.022

Riga P, Charpentier S (1999) Simulation of nitrogen dynamics in an alluvial sandy soil with drip fertigation of apple trees. Soil Use Manag 15:34-40. doi:10.1111/j.1475-2743.1999.tb00061.x

Ripoche A, Rellier J, Martin-Clouaire R, Paré N, Biarnès A, Gary C (2011) Modelling adaptive management of intercropping in vineyards to satisfy agronomic and environmental performances under Mediterranean climate. Environ Model Softw 26:1467-1480. doi:10.1016/j.envsoft.2011.08.003

Robinson DW, O'Kennedy ND (1978) The effect of the overall herbicide systems of soil management on the growth and yield of apple trees "golden Delicious.". Sci Hortic (Amsterdam) 9:127-136

Robinson T, Lakso A, Ren Z (1991) Modifying apple tree canopies for improved production efficiency. Hortscience 26:1005-1012

Robinson T, Wünsche J, Lakso A (1993) The influence of orchards system and pruning severity on yield, light interception, conversion efficiency, partitioning index and leaf area index. Acta Hortic 349: 123-128. Doi: 10.17660/ActaHortic.1993.349.17

Rodríguez-Entrena M, Barreiro-Hurlé J, Gómez-Limón J, EspinosaGoded M, Castro-Rodríguez J (2012) Evaluating the demand for carbon sequestration in olive grove soils as a strategy toward mitigating climate change. J Environ Manag 112:368-376. doi:10.1016/ j.jenvman.2012.08.004

Rodríguez J, Beard T, Bennett E, Cumming G, Cork S, Agard J, Dobson A, Peterson G (2006) Trade-offs across space, time, and ecosystem services. Ecol Soc 11:28

Rosa García R, Miñarro M (2014) Role of floral resources in the conservation of pollinator communities in cider-apple orchards. Agric Ecosyst Environ 183:118-126. doi:10.1016/j. agee.2013.10.017

Sagoff M (2011) The quantification and valuation of ecosystem services. Ecol Econ 70:497-502. doi:10.1016/j.ecolecon.2010.10.006

Sandhu HS, Wratten SD, Cullen R (2010) Organic agriculture and ecosystem services. Environ Sci Pol 13:1-7. doi:10.1016/j.envsci.2009. 11.002

Sandhu HS, Wratten SD, Cullen R, Case B (2008) The future of farming: the value of ecosystem services in conventional and organic arable land. An experimental approach. Ecol Econ 64:835-848. doi:10. 1016/j.ecolecon.2007.05.007
Saure M (1990) External control of anthocyanin formation in apple. Sci Hortic (Amsterdam) 42:181-218. doi:10.1016/0304-4238(90) 90082-P

Schäckermann J, Pufal G, Mandelik Y, Klein A (2015) Agro-ecosystem services and dis-services in almond orchards are differentially influenced by the surrounding landscape. Ecol Entomol 40:12-21. doi: 10.1111/een.12244

Schellhorn NA, Parry HR, Macfadyen S, Wang Y, Zalucki MP (2015) Connecting scales: achieving in-field pest control from areawide and landscape ecology studies. Insect Sci 22:35-51. doi:10.1111/17447917.12161

Schipanski ME, Barbercheck M, Douglas MR, Finney DM, Haider K, Kaye JP, Kemanian AR, Mortensen DA, Ryan MR, Tooker J, White C (2014) A framework for evaluating ecosystem services provided by cover crops in agroecosystems. Agric Syst 125:12-22. doi:10. 1016/j.agsy.2013.11.004

Schmid A, Weibel F (2000) Das sandwich system - ein Verfahren zur herbizidfreien Baumstreifenbewirtschaftung? [the sandwich system, a procedure for herbicide free in-row weed control?]. Obstbau 25: 214-217

Simon S, Bouvier J, Debras J, Sauphanor B (2010) Biodiversity and pest management in orchard systems. A review. Agron Sustain Dev 30: 139-152. doi:10.1051/agro/2009013

Simon S, Lauri P-EP, Brun L, Defrance H, Sauphanor B (2006) Does fruit-tree architecture manipulation affect the development of pests and pathogens? J Hortic Sci Biotechnol 81:765-773

Simon S, Morel K, Durand E, Brevalle G, Girard T, Lauri P (2012) Aphids at crossroads: when branch architecture alters aphid infestation patterns in the apple tree. Trees-Struct Funct 26:273-282. doi: 10.1007/s00468-011-0629-8

Six J, Freyn SD, Thietn RK, Batten K (2006) Bacterial and fungal contributions to carbon sequestration in agroecosystems. Soil Sci Soc Am J 70:555. doi:10.2136/sssaj2004.0347

Sofo A, Nuzzo V, Palese A, Xiloyannis C, Celano G, Zukowskyj P, Dichio B (2005) Net CO2 storage in mediterranean olive and peach orchards. Sci Hortic (Amsterdam) 107:17-24. doi:10.1016/j.scienta. 2005.06.001

Sokalska DI, Haman DZ, Szewczuk A, Sobota J, Deren D (2009) Spatial root distribution of mature apple trees under drip irrigation system. Agric Water Manag 96:917-924. doi:10.1016/j.agwat.2008.12.003

Song B, Wu H, Kong Y, Zhang J, Du Y, Hu J, Yao Y (2010) Effects of intercropping with aromatic plants on the diversity and structure of an arthropod community in a pear orchard. BioControl 55:741-751. doi:10.1007/s10526-010-9301-2

Souty M, Génard M, Reich M, Albagnac G (1999) Effect of assimilate supply on peach fruit maturation and quality. Can J Plant Sci 79: 259-268

Stern RA, Eisikowitch D, Dag A (2001) Sequential introduction of honeybee colonies and doubling their density increases cross-pollination, fruit-set and yield in "red Delicious" apple. J Hortic Sci Biotechnol 76:17-23

Stopar M, Bolcina U, Vanzo A, Vrhovsek U (2002) Lower crop load for cv. Jonagold apples (Malus $\mathrm{x}$ domestica Borkh.) increases polyphenol content and fruit quality. J Agric Food Chem 50:1643-1646. doi:10.1021/jf011018b

Strullu L, Beaudoin N, de Cortàzar Atauri IG, Mary B (2014) Simulation of biomass and nitrogen dynamics in perennial organs and shoots of Miscanthus $\times$ Giganteus using the STICS model. BioEnergy Res 7: 1253-1269. doi:10.1007/s12155-014-9462-4

Susfalk RB, Johnson DW (2002) Ion exchange resin based soil solution lysimeters and snowmelt solution collectors. Commun Soil Sci Plant Anal 33:1261-1275. doi:10.1081/CSS-120003886

Sykes SR (2008) The effect on Citrus fruit of excluding pollinating insects at flowering and implications for breeding new seedless cultivars. J Hortic Sci Biotechnol 83:713-718. doi:10.1080/14620316. 2008.11512449 
Syswerda SP, Robertson GP (2014) Ecosystem services along a management gradient in Michigan (USA) cropping systems. Agric Ecosyst Environ 189:28-35. doi:10.1016/j.agee.2014.03.006

Tagliavini M, Scudellazi D, Marangoni B, Toselli M (1996) Nitrogen fertilization management in orchards to reconcile productivity and environmental aspects. Fertil Res 43:93-102. doi:10.1007/ BF00747687

Tagliavini M, Tonon G, Scandellari F, Quiñones A, Palmieri S, Menarbin G, Gioacchini P, Masia A (2007) Nutrient recycling during the decomposition of apple leaves (Malus domestica) and mowed grasses in an orchard. Agric Ecosyst Environ 118:191-200. doi:10.1016/j. agee.2006.05.018

Taylor JA, Praat JP, Bollen AF (2007) Spatial variability of kiwifruit quality in orchards and its implications for sampling and mapping. Hortscience 42:246-250

Teravest D, Smith J, Carpenter-Boggs L, Granatstein D, Hoagland L, Reganold J (2011) Soil carbon pools, nitrogen supply, and tree performance under several groundcovers and compost rates in a newly planted apple orchard. Hortscience 46:1687-1694

Thiel A, Schleyer C, Plieninger T (2012) Wolves are mobile, while fruit trees are not! How characteristics of resources and supranational regulatory frameworks shape the provision of biodiversity and ecosystem Services in Germany. Environ Policy Gov 22:189-204. doi: 10.1002/eet.1578

Thies C (1999) Landscape structure and biological control in agroecosystems. Science (80- ) 285:893-895. doi:10.1126/science. 285.5429 .893

Thompson H (2003) Behavioural effects of pesticides in bees -their potential for use in risk assessment. Ecotoxicology 12:317-330

Toselli M, Flore J, Zavalloni C, Marangoni B (2000) Nitrogen partitioning in apple trees as affected by application time. HortTechnology 10:136-141

Tribouillois H, Cohan J-P, Justes E (2016) Cover crop mixtures including legume produce ecosystem services of nitrate capture and green manuring: assessment combining experimentation and modelling. Plant Soil 401:347-364. doi:10.1007/s11104-015-2734-8

Tsonkova P, Quinkenstein A, Böhm C, Freese D, Schaller E (2014) Ecosystem services assessment tool for agroforestry (ESAT-A): an approach to assess selected ecosystem services provided by alley cropping systems. Ecol Indic 45:285-299. doi:10.1016/j.ecolind. 2014.04.024

Vaissière B, Morison N, Crété X, Ferré G, Matti M, Vilain J (2000) Incidence des filets paragrêle sur les abeilles et la pollinisation des pommiers. Arboric Fruitière 544:19-25

van Oudenhoven A, Petz K, Alkemade R, Hein L, de Groot R (2012) Framework for systematic indicator selection to assess effects of land management on ecosystem services. Ecol Indic 21:110-122. doi:10.1016/j.ecolind.2012.01.012
Vasseur C, Joannon A, Aviron S, Burel F, Meynard J, Baudry J (2013) The cropping systems mosaic: how does the hidden heterogeneity of agricultural landscapes drive arthropod populations? Agric Ecosyst Environ 166:3-14. doi:10.1016/j.agee.2011.10.012

Volz R, Tustin D, Ferguson I (1996) Pollination effects on fruit mineral composition, seeds and cropping characteristics of "Braeburn" apple trees. Sci Hortic (Amsterdam) 66:169-180. doi:10.1016/S03044238(96)00934-X

Wallace K (2007) Classification of ecosystem services: problems and solutions. Biol Conserv 139:235-246. doi:10.1016/j.biocon.2007. 07.015

White R (2006) Principles and practices of soil science: the soil as a natural resource - 4th Edition. Blackwell Publishing

Willaume M, Lauri P, Sinoquet H (2004) Light interception in apple trees influenced by canopy architecture manipulation. Trees - Struct Funct 18:705-713. doi:10.1007/s00468-004-0357-4

Wu T, Wang Y, Yu C, Chiarawipa R, Zhang X, Han Z, Wu L (2012) Carbon sequestration by fruit trees - chinese apple orchards as an example. PLoS One 7:e38883. doi:10.1371/journal.pone.0038883

Wünsche J, Lakso A, Robinson T, Lenz F, Denning S (1996) The bases of productivity in apple production systems: the role of light interception by different shoot types. J Am Soc Hortic Sci 121:886-893

Wyss E (1995) The effects of weed strips on aphids and aphidophagous predators in an apple orchard. Entomol Exp Appl 75:43-49. doi:10. 1111/j.1570-7458.1995.tb01908.x

Xia G, Cheng L, Lakso A, Goffinet M (2009) Effects of nitrogen supply on source-sink balance and fruit size of "Gala" apple trees. J Am Soc Hortic Sci 134:126-133

Zanotelli D, Montagnani L, Manca G, Scandellari F, Tagliavini M (2015) Net ecosystem carbon balance of an apple orchard. Eur J Agron 63: 97-104. doi:10.1016/j.eja.2014.12.002

Zanotelli D, Montagnani L, Manca G, Tagliavini M (2013) Net primary productivity, allocation pattern and carbon use efficiency in an apple orchard assessed by integrating eddy covariance, biometric and continuous soil chamber measurements. Biogeosciences 10:30893108. doi:10.5194/bg-10-3089-2013

Zhang W, Ricketts T, Kremen C, Carney K, Swinton S (2007) Ecosystem services and dis-services to agriculture. Ecol Econ 64:253-260. doi: 10.1016/j.ecolecon.2007.02.024

Zhu X, Burger M, Doane T, Horwath W (2013) Ammonia oxidation pathways and nitrifier denitrification are significant sources of $\mathrm{N} 2 \mathrm{O}$ and NO under low oxygen availability. PNAS 110:6328 6333. doi:10.1073/pnas.1219993110/-/DCSupplemental.www. pnas.org/cgi/doi/10.1073/pnas.1219993110

Zibordi M, Domingos S, Corelli Grappadelli L (2009) Thinning apples via shading: an appraisal under field conditions. J Hortic Sci Biotechnol 84:138-144. doi:10.1080/14620316.2009.11512611 